\title{
Synergizing strong metal-support interactions and spatial confinement boosts dynamics of atomic nickel for hydrogenations
}

Jian Gu

University of Science and Technology of China

Minzhen Jian

University of Science and Technology of China

Li Huang

University of Science and Technology of China

Zhihu Sun

University of Science and Technology of China

Yang Pan

University of Science and Technology of China

Jiuzhong Yang

University of Science and Technology of China

https://orcid.org/0000-0002-7076-3412

Wu Wen

University of Science and Technology of China

Yue Lin

University of Science \& Technology of China https://orcid.org/0000-0001-5333-511X

Hui-Juan Wang

University of Science and Technology of China

\section{Xinyu Liu}

University of Science and Technology of China

\section{Leilei Wang}

University of Science and Technology of China

\section{Xianxian Shi}

University of Science and Technology of China

\section{Xiaohui Huang}

University of Science and Technology of China

\section{Lina Cao}

University of Science and Technology of China

https://orcid.org/0000-0002-0792-5482

\section{Si Chen}

University of Science and Technology of China

Xu-Sheng Zheng 
University of Science and Technology of China

\section{Haibin Pan}

University of Science and Technology of China

Junfa Zhu

University of Science and Technology of China https://orcid.org/0000-0003-0888-4261

\section{Shiqiang Wei}

University of Science and Technology of China https://orcid.org/0000-0002-2052-1132

\section{Wei-Xue Li}

University of Science and Technology of China https://orcid.org/0000-0002-5043-3088

Junling Lu ( $\sim$ junling@ustc.edu.cn )

University of Science and Technology of China https://orcid.org/0000-0002-2607-6869

\section{Article}

Keywords: atomically dispersed metal catalysts, atomic nickel

Posted Date: December 29th, 2020

DOl: https://doi.org/10.21203/rs.3.rs-126470/v1

License: (1) (1) This work is licensed under a Creative Commons Attribution 4.0 International License. Read Full License

Version of Record: A version of this preprint was published at Nature Nanotechnology on July 26th, 2021. See the published version at https://doi.org/10.1038/s41565-021-00951-y. 


\section{Abstract}

Atomically dispersed metal catalysts maximize atom efficiency and display unique catalytic properties compared to regular metal nanoparticles. However, achieving high reactivity while still preserving high stability at high loadings remains as a grand challenge. Here we solve the challenge by synergizing strong metal-support interactions and spatial confinement, which enable to fabricate highly loaded (3.1 $w t \%)$, active and stable atomic $\mathrm{Ni}$ and dense atomic Cu grippers (8.1 wt\%) on a graphitic $\mathrm{C}_{3} \mathrm{~N}_{4}$ support. For semi-hydrogenation of acetylene in excess of ethylene, the fabricated catalyst shows 11 times higher activity than the atomic $\mathrm{Ni}$ alone, high ethylene selectivity (90\%), and high stability against both sintering and coke formation for $350 \mathrm{~h}$. Comprehensive microscopic and spectroscopic characterization and theoretical calculations reveal the active site of the bridging Ni confined in two hydroxylated Cu grippers, whose structure changes dynamically by breaking interfacial Ni-support bonds upon reactant adsorption and making these bonds upon product desorption. Such a dynamic effect confers high activity/selectivity and high stability, providing an avenue to rational design of efficient, stable, highly loaded, yet atomically dispersed catalysts.

\section{Introduction}

Supported atomically dispersed catalysts (SADCs) have recently drawn great attention in numerous reactions for their maximized atom efficiency ${ }^{1-3}$. Exclusive site homogeneity, distinct energetics and spatial site confinement endow SADCs very attractive in high selectivity and alleviated coke formation in conversion of hydrocarbons ${ }^{4-6}$, sharply distinct from the low selectivity and heavy coke formation on metal nanoparticle (NP) catalysts ${ }^{7}$. However, owing to the drastically increased surface free energy, stability of the atomically dispersed metal species under reaction conditions, especially at high metal loadings has been the key issue to significantly limit the overall performance, restraining their practical applications ${ }^{8}$.

Realization of a highly-loaded and stable SADCs for hydrogenation reactions is particularly challenging, because atomically dispersed active metal species often show higher mobility in reducing environments ${ }^{9}$. For instance, in semi-hydrogenation of acetylene in excess ethylene, a crucial industrial process operated at a scale of billions of tons per annum to purify alkene streams ${ }^{10,11}$, severe metal aggregations occurred even for low-loaded SADCs, which sequentially generated heavy coke formation, an even worse scenario to further accelerate catalyst deactivation to a short life time ${ }^{12}$. Increasing metal-support interactions $(\mathrm{MSIs})^{13,14}$ or confining the active metal species in restrained spaces (eg. micropores) ${ }^{15}$ are two widely adopted methodologies to achieve for higher stability. However, too strong MSI might over stabilize the active sites, hindering its activation to reactants/intermediates ${ }^{14,16}$; confinement of the metal species in micropores might also limit mass transfers ${ }^{15,17}$. Consequently, a seesaw relation between stability and activity have been often observed, obscuring the tremendous efforts for optimizing the catalytic performance of SADCs ${ }^{18-20}$. 
In this work, we report that the challenge can be solved by synergizing strong metal-support interactions (SMSIs) and spatial confinement to break the seesaw relationship between activity and stability of SADCs at high metal loadings. Specifically, strong Ni-N/C interaction and spatial confinement applied by dense atomic $\mathrm{Cu}$ grippers (8.1 wt\%) on a graphitic $\mathrm{C}_{3} \mathrm{~N}_{4}$ support are simultaneously utilized, endowing a great structural flexibility and reversible bond breakings and makings of the supported highly loaded (3.1wt\%) atomic Ni upon reactant adsorption and product desorption, respectively. Such a dynamic effect not only facilitates the acetylene adsorption for high activity by achieving a full acetylene conversion at a moderate temperature of $\sim 170{ }^{\circ} \mathrm{C}$ along with a high ethylene selectivity of $90 \%$, but also ensures high thermal/chemical stability and unprecedented inhibition of coke formation by exhibiting an unprecedented long-durability of at least $350 \mathrm{~h}$, far superior to the conventional atomically-dispersed $\mathrm{Ni}$ catalyst in terms of stability, activity, and selectivity.

\section{Results}

Synthesis and catalytic performance. $\mathrm{G}-\mathrm{C}_{3} \mathrm{~N}_{4}$, containing periodic triangular cavities with six coordinately unsaturated pyridinic nitrogen $\left(\mathrm{N}_{\mathrm{py}}\right)$ atoms, provides a perfect platform for anchoring active and dense metal species ${ }^{21,22}$. Computational screening was first conducted by density functional theory (DFT) calculations to identify the optimum candidates among group VIII and IB metals on $\mathrm{g}-\mathrm{C}_{3} \mathrm{~N}_{4}$. $\mathrm{Ni}$ and $\mathrm{Cu}$ were found to exhibit strong binding to $\mathrm{g}-\mathrm{C}_{3} \mathrm{~N}_{4}$ underneath along with low formation energy compared to the other metals (Supplementary Table 1), therefore the most promising candidates for highly loaded and stable metals on $\mathrm{g}-\mathrm{C}_{3} \mathrm{~N}_{4}$ with atomic dispersion.

Inspired by these results, atomic layer deposition (ALD), a gas-phase technique relying on sequential selflimiting molecular-level surface reactions ${ }^{23,24}$, was employed to deposit $\mathrm{Cu}$ and $\mathrm{Ni}$ on g- $\mathrm{C}_{3} \mathrm{~N}_{4}$ with near atomic precision ${ }^{25,26}$. Atomically dispersed $\mathrm{Cu}$ grippers were first fabricated on $\mathrm{g}-\mathrm{C}_{3} \mathrm{~N}_{4}$ by $\mathrm{Cu}$ ALD (denoted as $\mathrm{Cu}_{1} / \mathrm{g}-\mathrm{C}_{3} \mathrm{~N}_{4}$ ), and the atomic dispersion of the $\mathrm{Cu}$ grippers, even at a saturated loading of as high as $11.2 \mathrm{wt}$ \% by five Cu ALD cycles was confirmed by X-ray adsorption spectroscopy (XAS) and aberration-corrected high-angle annular dark-field scanning transmission electron microscopy (HAADFSTEM) (Supplementary Figs. 1a, 2-5 and Supplementary Table 2). At sub-saturation coverages of $\mathrm{Cu}$, the open $\mathrm{N}_{\text {py }}$ atoms along with the neighboring $\mathrm{Cu}$ atoms together provide abundant anchor sites for guest atoms, analogous to that of stabilization of metal atoms by pincer ligands in organometallic chemistry 27 . $\mathrm{Next}, \mathrm{Ni}_{y} \mathrm{Cu}_{1} / \mathrm{g}-\mathrm{C}_{3} \mathrm{~N}_{4}$ catalysts were synthesized by depositing $\mathrm{Ni}$ on sub-saturated $\mathrm{Cu}_{1} / \mathrm{g}-\mathrm{C}_{3} \mathrm{~N}_{4}(y$ is the atomic ratio of $\mathrm{Ni}$ to $\mathrm{Cu}$ ) using $\mathrm{NiO}_{x} \mathrm{ALD}$; therein isolated $\mathrm{Ni}$ atoms were gripped and stabilized jointly by the open $\mathrm{N}_{\text {py }}$ sites through SMSIs and adjacent $\mathrm{Cu}$ atom grippers through spatial confinements, as seen in the schematic illustration and morphology in Supplementary Figs. 6 and 7, respectively. This is supported by the decrease of Ni loadings as increase of the number Cu ALD cycles, and the negligible Ni deposition on the saturated $\mathrm{Cu}_{1} / \mathrm{g}-\mathrm{C}_{3} \mathrm{~N}_{4}$ sample (Supplementary Fig. $1 \mathrm{~b}$ ). For comparison, $\mathrm{Ni}_{1} / \mathrm{g}-\mathrm{C}_{3} \mathrm{~N}_{4}$ SADCs were also fabricated by executing one cycle of $\mathrm{NiO}_{x}$ ALD directly on $\mathrm{g}^{-} \mathrm{C}_{3} \mathrm{~N}_{4}$ (Supplementary Figs. 8-12 and Supplementary Table 3). HAADF-STEM showed that $\mathrm{Cu}_{1} / \mathrm{g}-\mathrm{C}_{3} \mathrm{~N}_{4}, \mathrm{Ni} \mathrm{Ni}_{1} / \mathrm{g}-\mathrm{C}_{3} \mathrm{~N}_{4}$, and $\mathrm{Ni}_{7} \mathrm{Cu} \mathrm{u}_{x} / \mathrm{g}-\mathrm{C}_{3} \mathrm{~N}_{4}$ 
catalysts were all atomically dispersed and thermally stable at $350{ }^{\circ} \mathrm{C}$ under $\mathrm{H}_{2}$ (Supplementary Figs. 13$15)$, in line with the above theoretical predictions. Next, three samples, $\mathrm{Cu}_{1} / \mathrm{g}-\mathrm{C}_{3} \mathrm{~N}_{4}$ (8.1 wt.\%), Ni $/ \mathrm{g}-\mathrm{C}_{3} \mathrm{~N}_{4}$ (3.1 wt.\%) and $\mathrm{Ni}_{1} \mathrm{Cu}_{2} / \mathrm{g}-\mathrm{C}_{3} \mathrm{~N}_{4}$ with similar loadings of $\mathrm{Cu}$ and $\mathrm{Ni}(8.1 \mathrm{wt} . \%$ and $3.1 \mathrm{wt} . \%$, a mole ratio of 2.4:1, respectively), were tested for catalytic hydrogenation.

Selective hydrogenation of acetylene in excess ethylene was conducted in a quartz tube plug-flow reactor. We found that $\mathrm{Cu}_{1} / \mathrm{g}-\mathrm{C}_{3} \mathrm{~N}_{4}$ was nearly inactive and reached a maximum acetylene conversion of only $10 \%$ with a low ethylene selectivity of $\sim 60 \%$ at $214^{\circ} \mathrm{C}$ (Fig. $1 \mathrm{a}, 1 \mathrm{~b}$ ). The $\mathrm{Ni}_{1} / \mathrm{g}-\mathrm{C}_{3} \mathrm{~N}_{4}$ catalyst performed slightly better, achieving $33 \%$ conversion and $\sim 85 \%$ ethylene selectivity at $260{ }^{\circ} \mathrm{C}$. Surprisingly, the $\mathrm{Ni}_{1} \mathrm{Cu}_{2} / \mathrm{g}-\mathrm{C}_{3} \mathrm{~N}_{4}$ catalyst showed a much higher activity, $100 \%$ conversion at $\sim 170{ }^{\circ} \mathrm{C}$. Importantly, the ethylene selectivity was at least as high as $90 \%$ even at the full acetylene conversion, which is vital for the practical removal of acetylene impurity from ethylene down to a few parts per million (ppm) without consuming the ethylene $e^{28}$. The corresponding activity was $7.01 \mathrm{~h}^{-1}$ at $160{ }^{\circ} \mathrm{C}$, which is about 11 and 58 times higher than that of $\mathrm{Ni}_{1} / \mathrm{g}-\mathrm{C}_{3} \mathrm{~N}_{4}$ and $\mathrm{Cu}_{1} / \mathrm{g}-\mathrm{C}_{3} \mathrm{~N}_{4}$, respectively (Fig. 1c). Though $\mathrm{Cu}$ alone was much less active with poor ethylene selectivity, its presence in $\mathrm{Ni}_{1} \mathrm{Cu}_{2} / \mathrm{g}-\mathrm{C}_{3} \mathrm{~N}_{4}$ promoted both activity and selectivity. This was further confirmed by

the corresponding kinetics measurements with less amounts of catalysts, where apparent activation energies were $45.1,86.5$, and $132.9 \mathrm{~kJ} / \mathrm{mol}$ for $\mathrm{Ni}_{1} \mathrm{Cu}_{2} / \mathrm{g}-\mathrm{C}_{3} \mathrm{~N}_{4}, \mathrm{Ni}_{1} / \mathrm{g}-\mathrm{C}_{3} \mathrm{~N}_{4}$, and $\mathrm{Cu}_{1} / \mathrm{g}-\mathrm{C}_{3} \mathrm{~N}_{4}$, respectively (Supplementary Fig. 16).

Remarkably, in addition to high thermal stability, the $\mathrm{Ni}_{1} \mathrm{Cu}_{2} / \mathrm{g}-\mathrm{C}_{3} \mathrm{~N}_{4}$ catalyst showed an unprecedented chemical stability under hydrogenation conditions, without any visible decline in either activity or selectivity for at least $350 \mathrm{~h}$ at $160^{\circ} \mathrm{C}$, and the used sample remained structurally intact (Fig. $1 \mathrm{~d}$ and Supplementary Figs. 17-19). In sharp contrast, $\mathrm{Ni}_{1} / \mathrm{g}-\mathrm{C}_{3} \mathrm{~N}_{4}$ showed a slight increase of acetylene conversion in the first $\sim 6 \mathrm{~h}$, and then deactivated rapidly with an activity loss of $\sim 50 \%$ in about $50 \mathrm{~h}$ at temperatures of $200^{\circ} \mathrm{C}$ (Fig. 1d). The initial increase of acetylene conversion is likely due to agglomeration of $\mathrm{Ni}$ atoms into $\mathrm{Ni}$ particles under reaction conversions as evidenced by $\mathrm{X}$-ray diffraction (XRD) and HAADF-STEM measurements (Supplementary Figs. 19 and 20).

To check for the possible formation of green oils, the dominant form of coke in this reaction ${ }^{29-33}$, highly sensitive state-of-the-art in situ synchrotron vacuum ultraviolet photoionization mass spectrometry (SVUV-PIMS) measurements were employed to detect the volatile green oils at the reactor outlet. We found that besides $C_{2}$ species, there were considerable gaseous $C_{3}-C_{8}$ species produced on $N i_{1} / g-C_{3} N_{4}$ (Fig. 1e and Supplementary Fig. 21), indicating the facile formation of green oils. In contrast, there was no higher hydrocarbons observed except a trace amount of $\mathrm{C}_{4} \mathrm{H}_{8}$ on $\mathrm{Ni}_{1} \mathrm{Cu}_{2} / \mathrm{g}-\mathrm{C}_{3} \mathrm{~N}_{4}$, confirming unambiguously the complete inhibition of formation of green oils. After executing $2 \mathrm{~h}$ of reaction, temperature-programmed deposition (TPD) measurements using SVUV-PIMS were further conducted to analyze the possible accumulation of green oils on these two samples. Again, there were only trace amount of $\mathrm{C}_{4+}$ species found on $\mathrm{Ni}_{1} \mathrm{Cu}_{2} / \mathrm{g}-\mathrm{C}_{3} \mathrm{~N}_{4}$, and in sharp contrast, $\mathrm{C}_{3}-\mathrm{C}_{17}$ species were all heavily 
present on $\mathrm{Ni}_{1} / \mathrm{g}-\mathrm{C}_{3} \mathrm{~N}_{4}$ (Fig. $1 \mathrm{f}$ and Supplementary Figs. 22 and 23). Compared to those in situ SVUVPIMS measurements in Fig. 1e, considerable increase of $\mathrm{C}_{7+}$ species on $\mathrm{Ni}_{1} / \mathrm{g}-\mathrm{C}_{3} \mathrm{~N}_{4}$ during TPD measurements is attributed to their low vapor pressures, which endow them more prone to accumulate on the catalyst.

Table 1 | Catalytic performances of benchmark catalysts reported in literature in semihydrogenation of acetylene.

\begin{tabular}{|c|c|c|c|c|c|c|c|}
\hline Catalysts & Morphology & $\begin{array}{l}\text { Total transition metal } \\
\text { loadings (wt.\%) }\end{array}$ & $\begin{array}{c}\text { Ethylene } \\
\text { selectivity (\%) }\end{array}$ & $\begin{array}{l}\text { TOS } \\
\text { (h) }\end{array}$ & $\begin{array}{c}\text { Average deactivation } \\
\text { rate }^{\mathrm{b}}(\% / \mathrm{h})\end{array}$ & $\begin{array}{c}\text { Coke } \\
\text { formation }\end{array}$ & Notes \\
\hline $\mathrm{Ni}_{1} \mathrm{Cu}_{2} / \mathrm{g}-\mathrm{C}_{3} \mathrm{~N}_{4}$ & $\begin{array}{l}\text { Trimeric } \\
\text { ions }\end{array}$ & 11.2 & 90 & 350 & 0 & N.D. ${ }^{f}$ & $\begin{array}{l}\text { This } \\
\text { work }\end{array}$ \\
\hline $\mathrm{Ni}_{1} / \mathrm{g}-\mathrm{C}_{3} \mathrm{~N}_{4}$ & Single ions & 3.1 & 85 & 50 & 0.71 & Yes & $\begin{array}{l}\text { This } \\
\text { work }\end{array}$ \\
\hline Na-Ni@CHA & Single ions & 3.5 & 97 & 50 & 0.28 & Yes & $\operatorname{Ref}^{31}$ \\
\hline $\mathrm{Ni}$ SAs/N-C & Single ions & 1.5 & 90 & 18 & 0.61 & N.A. ${ }^{e}$ & $\operatorname{Ref}^{34}$ \\
\hline $\mathrm{Cu}_{1} / \mathrm{ND} @ \mathrm{G}$ & Single ions & 0.2 & 98 & 60 & 0 & N.A.e & $\operatorname{Ref}^{10}$ \\
\hline $0.5 \mathrm{Cu} / \mathrm{Al}_{2} \mathrm{O}_{3}$ & Single ions & 0.5 & 91 & 40 & 0 & Yes & $\operatorname{Ref}^{35}$ \\
\hline $\mathrm{Pd}_{1} / \mathrm{ND} @ \mathrm{G}$ & Single ions & 0.11 & 90 & 30 & 0 & N.D. ${ }^{f}$ & $\operatorname{Ref}^{36}$ \\
\hline ISA-Pd/MPNC & Single ions & 0.043 & 82 & 20 & 0.05 & N.A. ${ }^{e}$ & $\operatorname{Ref}^{37}$ \\
\hline $\mathrm{AgPd}_{0.01} / \mathrm{SiO}_{2}$ & SAAs $^{\mathrm{C}}$ & 4.91 & 80 & 24 & 0.25 & N.A. ${ }^{e}$ & $\operatorname{Ref}^{38}$ \\
\hline $\mathrm{AuPd}_{0.01} / \mathrm{SiO}_{2}$ & SAAs $^{\mathrm{C}}$ & 4.92 & 70 & 24 & 0.71 & Yes & $\operatorname{Ref}^{39}$ \\
\hline $\mathrm{NiGa}$ & $\mathrm{IMC}^{\mathrm{d}}$ & 10.0 & 75 & 24 & 0.04 & Yes & $\operatorname{Ref}^{40}$ \\
\hline $\mathrm{Ni}_{3} \mathrm{Ga} / \mathrm{MgAl}_{2} \mathrm{O}_{4}$ & $\mathrm{IMC}^{\mathrm{d}}$ & 2.0 & 77 & 24 & 0.16 & Yes & $\operatorname{Ref}^{41}$ \\
\hline $\mathrm{Al}_{13} \mathrm{Fe}_{4}$ & $\mathrm{IMC}^{\mathrm{d}}$ & N.A. ${ }^{e}$ & 82 & 20 & 0.55 & Yes & $\operatorname{Ref}^{42}$ \\
\hline PdZn & $\mathrm{IMC}^{\mathrm{d}}$ & N.A. ${ }^{e}$ & 91 & 20 & 0.20 & Yes & $\operatorname{Ref}^{43}$ \\
\hline Nano-GaPd ${ }_{2}$ & $\mathrm{IMC}^{\mathrm{d}}$ & N.A. ${ }^{e}$ & 72 & 20 & 0.25 & Yes & $\operatorname{Ref} 44$ \\
\hline pre-NiCu/MMO & $\begin{array}{l}\text { Bimetallic } \\
\text { NPs }\end{array}$ & 19.7 & 70 & 16 & 1.56 & Yes & $\operatorname{Ref}^{45}$ \\
\hline $\mathrm{NiIn} / \mathrm{SiO}_{2}$ & $\begin{array}{l}\text { Bimetallic } \\
\text { NPs }\end{array}$ & 8.0 & 35 & 10 & 6.91 & Yes & $\operatorname{Ref}^{46}$ \\
\hline
\end{tabular}

${ }^{a}$ Ethylene selectivity was determined at near $100 \%$ acetylene conversion; ${ }^{\text {b }}$ The average deactivation rate was determined by the decrease of acetylene conversion divided by TOS; ${ }^{c}$ single-atom alloys; dintermetallic compound; enon-available; ${ }^{\text {nnon-detectable. }}$

Coke formation under hydrogenation conditions was further monitored by in situ thermogravimetric analysis (TGA). After $12 \mathrm{~h}$, the weight-gain of $\mathrm{Ni}_{1} \mathrm{Cu}_{2} / \mathrm{g}-\mathrm{C}_{3} \mathrm{~N}_{4}$ was negligible, close to the thermal noise. Whereas, the $\mathrm{Ni}_{1} / \mathrm{g}-\mathrm{C}_{3} \mathrm{~N}_{4}$ catalyst showed a considerable weight increase by $7.6 \%$ (Fig. $1 \mathrm{~g}$ ), in line with the above SVUV-PIMS measurements. X-ray diffraction (XRD) revealed graphitic coke formed on the used $\mathrm{Ni}_{1} / \mathrm{g}-\mathrm{C}_{3} \mathrm{~N}_{4}$ (Supplementary Fig. 19), but not on the used $\mathrm{Ni}_{1} \mathrm{Cu}_{2} / g-\mathrm{C}_{3} \mathrm{~N}_{4}$. Clearly, the capability of cokeinhibition and long-durability achieved on the $\mathrm{Ni}_{1} \mathrm{Cu}_{2} / \mathrm{g}-\mathrm{C}_{3} \mathrm{~N}_{4}$ catalyst are unprecedented, far superior to the benchmark catalysts of metal single-atoms, intermetallic compounds, and NPs reported in literature (Table 1 and Supplementary Tables 4-6). Such simultaneous achievement of complete coke-inhibition, high activity, high ethylene selectivity, as well as outstanding thermal and chemical stability by $\mathrm{Ni}_{1} \mathrm{Cu}_{2} / \mathrm{g}$ $\mathrm{C}_{3} \mathrm{~N}_{4}$ was also found in semi-hydrogenation of 1,3-butadiene in excess propene (Supplementary Fig. 24), rendering this material promising for wide applications. 
Structural characterization. To identify the active sites and reveal the structure-activity relationships of the $\mathrm{Ni}_{1} \mathrm{Cu}_{2} / \mathrm{g}-\mathrm{C}_{3} \mathrm{~N}_{4}$ catalyst, a number of atomic-resolution STEM images of these samples at different locations were collected. Statistical analysis indicates that there were mainly three structural motifs, namely, single atoms, linear trimers and triangular trimers with distinct composition and populations, respectively (Fig. 2a, Supplementary Figs. 5, 7, and 12). For $\mathrm{Cu}_{1} / \mathrm{g}-\mathrm{C}_{3} \mathrm{~N}_{4}$, the single atoms were the most populated at $68 \%$, followed by the linear trimers at $20 \%$ and the triangular trimers at $12 \%$ (Fig. $2 \mathrm{~b}$ ). Subsequent $\mathrm{Ni}$ deposition forms $\mathrm{Ni}_{1} \mathrm{Cu}_{2} / \mathrm{g}-\mathrm{C}_{3} \mathrm{~N}_{4}$, and the linear trimers increased dramatically to $71 \%$ in expense of the single atoms to $18 \%$, while the triangular trimers remained $\sim 11 \%$. This suggests that most of the pre-deposited single $\mathrm{Cu}$ atoms might be bridged by added $\mathrm{Ni}$ atoms to form new linear trimers (Supplementary Fig. 6). The overall lengths of the linear trimers were $5.66 \pm 0.20 \AA$ composing by two unequal atom-atom distances of $2.61 \pm 0.14$ and $3.04 \pm 0.13 \AA$ in average (Fig. 2c and Supplementary Fig. 7). Since there were no triangular trimers observed in $\mathrm{Ni}_{1} / g-\mathrm{C}_{3} \mathrm{~N}_{4}(86 \%$ of the single atoms and $14 \%$ of the linear trimers, Supplementary Fig. 12), the triangular trimers in $\mathrm{Ni}_{1} \mathrm{Cu}_{2} / \mathrm{g}-\mathrm{C}_{3} \mathrm{~N}_{4}$ are the triangular trimers from $\mathrm{Cu}_{1} / \mathrm{g}-\mathrm{C}_{3} \mathrm{~N}_{4}$ and compose $\mathrm{Cu}$ only. Considering the negligible activity of $\mathrm{Cu}_{1} / \mathrm{g}-\mathrm{C}_{3} \mathrm{~N}_{4}$ and $\mathrm{Ni}_{1} / \mathrm{g}-\mathrm{C}_{3} \mathrm{~N}_{4}$ below $170{ }^{\circ} \mathrm{C}$, the exceptional overall performance of $\mathrm{Ni}_{1} \mathrm{Cu}_{2} / g-\mathrm{C}_{3} \mathrm{~N}_{4}$ should come solely from the new and prevailing linear trimers, which was extremely stable, even after $350{ }^{\circ} \mathrm{C}$ reduction and the long-term reaction test (Supplementary Figs. 15 and 18).

In situ X-ray photoemission spectroscopy (XPS) revealed the composition and chemical state of the $\mathrm{Ni}_{1} \mathrm{Cu}_{2} / \mathrm{g}-\mathrm{C}_{3} \mathrm{~N}_{4}$ catalyst, in particular the active linear trimers. Figure $2 \mathrm{~d}$ shows XPS spectra of the $\mathrm{Ni}_{1} \mathrm{Cu}_{2} / \mathrm{g}-\mathrm{C}_{3} \mathrm{~N}_{4}$ catalyst in the $\mathrm{Cu} 2 \mathrm{p}$, Ni $2 \mathrm{p}$ and $\mathrm{O} 1 \mathrm{~s}$ regions after reduction at $350^{\circ} \mathrm{C}$ for $2 \mathrm{~h}$ followed by exposing to the reaction gas at $160^{\circ} \mathrm{C}$ for another $1 \mathrm{~h}$. Irrespective of the treatments, the $\mathrm{Cu} 2 \mathrm{p}_{3 / 2}$ binding energy was invariant at $933.2 \mathrm{eV}$, an indication of $1^{+}$oxidation state ${ }^{27,47}$ (Fig. 2d and Supplementary Fig. 25). The $\mathrm{Ni} 2 \mathrm{p}_{3 / 2}$ binding energy was located at $855.8 \mathrm{eV}$, close to that of $\mathrm{Ni}(\mathrm{OH})_{2}{ }^{48}$. Along with this, considerable hydroxyl-type oxygen, with $01 \mathrm{~s}$ at $531.4 \mathrm{eV}$ was found. Since there were only trace of oxygen in $\mathrm{g}-\mathrm{C}_{3} \mathrm{~N}_{4}$ and $\mathrm{Cu}_{1} / \mathrm{g}-\mathrm{C}_{3} \mathrm{~N}_{4}$, the $\mathrm{OH}$ groups in $\mathrm{Ni}_{1} \mathrm{Cu}_{2} / \mathrm{g}-\mathrm{C}_{3} \mathrm{~N}_{4}$ were accompanied along with the $\mathrm{Ni}$ (Supplementary Figs. 25 and 26). Quantitative XPS analysis showed that the stoichiometric ratio between $\mathrm{O}$ and $\mathrm{Ni}$ was about 2:1. Taken together the results suggest that the active linear trimers are $\mathrm{Ni}_{1}(\mathrm{OH})_{2} \mathrm{Cu}_{2}$ complexes formed under reaction conditions. While we noticed that exposing $\mathrm{Ni}_{1} / \mathrm{g}-\mathrm{C}_{3} \mathrm{~N}_{4}$ catalyst to the reaction gas at $200{ }^{\circ} \mathrm{C}$ for another $1 \mathrm{~h}$ cause the formation of metallic Ni and NiO species (Supplementary Fig. 26), in line with the STEM observation (Supplementary Fig. 20).

To reveal the structure of the active $\mathrm{Ni}_{1}(\mathrm{OH})_{2} \mathrm{Cu}_{2}$ complexes on $\mathrm{Ni}_{1} \mathrm{Cu}_{2} / \mathrm{g}-\mathrm{C}_{3} \mathrm{~N}_{4}$ under reaction conditions, in situ XAS measurements were conducted (Supplementary Fig. 15). The extended X-ray absorption fine structure (EXAFS) curve of $\mathrm{Ni}_{1} \mathrm{Cu}_{2} / \mathrm{g}-\mathrm{C}_{3} \mathrm{~N}_{4}$ after $350{ }^{\circ} \mathrm{C}$ hydrogen reduction $\left(\mathrm{Ni}_{1} \mathrm{Cu}_{2} / \mathrm{g}-\mathrm{C}_{3} \mathrm{~N}_{4}-\mathrm{R}\right)$ exhibited a Ni K-edge spectrum with one main peak at $1.41 \AA$ and a weak peak at $2.21 \AA$ (Fig. 2e). The main peak was assigned to $\mathrm{Ni}-\mathrm{O} / \mathrm{N} / \mathrm{C}$ scattering, by comparison to $\mathrm{Ni}$ foil, $\mathrm{NiO}$, and nickel(II) phthalocyanine (NiPc). Furthermore, the EXAFS curve of $\mathrm{Ni}_{1} \mathrm{Cu}_{2} / \mathrm{g}-\mathrm{C}_{3} \mathrm{~N}_{4}$ under the hydrogenation condition $\left(\mathrm{Ni}_{1} \mathrm{Cu}_{2} / \mathrm{g}-\mathrm{C}_{3} \mathrm{~N}_{4}-\mathrm{H}\right)$ is very close to that of $\mathrm{Ni}_{1} \mathrm{Cu}_{2} / \mathrm{g}-\mathrm{C}_{3} \mathrm{~N}_{4}-\mathrm{R}$, indicating little variation in local coordination of the active 
$\mathrm{Ni}_{1}(\mathrm{OH})_{2} \mathrm{Cu}_{2}$ complexes in presence of acetylene and ethylene. To get a better understanding of the weak feature at 2.21 $\AA$, wavelet transform (WT) of the EXAFS spectrum was performed and showed that Ni$\mathrm{O} / \mathrm{N} / \mathrm{C}$ and $\mathrm{Ni}-\mathrm{Cu}$ coordination co-exists as evidenced by the shift of peak B toward to a higher $k$ value relative to peak A (Supplementary Fig. 27). Quantitative EXAFS fitting produced coordination numbers (CNs) for the nearest $\mathrm{Ni}-\mathrm{O} / \mathrm{N} / \mathrm{C}$ and the next-nearest Ni-Cu were 3.3 and 0.6 with bond distances of 1.95 and $2.90 \AA$ A respectively (Supplementary Fig. 28 and Supplementary Table 7). Similarly, at the Cu K-edge, the $\mathrm{Ni}_{1} \mathrm{Cu}_{2} / \mathrm{g}-\mathrm{C}_{3} \mathrm{~N}_{4}-\mathrm{R}$ and the $\mathrm{Ni}_{1} \mathrm{Cu}_{2} / \mathrm{g}-\mathrm{C}_{3} \mathrm{~N}_{4}-\mathrm{H}$ appeared the same structure, the main peak at $1.47 \AA$ was attributed to $\mathrm{Cu}-\mathrm{O} / \mathrm{N} / \mathrm{C}$ coordination, and the weak peak $2.33 \AA$ A was assigned to $\mathrm{Cu}-\mathrm{Cu} / \mathrm{Ni}$ coordination according to the WT map. Quantitative EXAFS fitting gave CNs for the nearest Cu-O/N and the nextnearest $\mathrm{Cu}-\mathrm{Cu} / \mathrm{Ni} \mathrm{CNs}$ of 1.7 and 0.5 with distances of $1.87 \AA$ and $2.83 \AA$ (Fig. 2f, Supplementary Fig. 29 and Supplementary Table 8).

Spectroscopic insight of the hydrogenation process. To further confirm the presence of hydroxyl groups in both $\mathrm{Ni}_{1} / \mathrm{g}-\mathrm{C}_{3} \mathrm{~N}_{4}$ and $\mathrm{Ni}_{1} \mathrm{Cu}_{2} / \mathrm{g}-\mathrm{C}_{3} \mathrm{~N}_{4}$, and investigate their catalytic roles in hydrogenation, in situ diffuse reflectance infrared Fourier transform spectroscopy (DRIFTS) measurements were carried out by alternatively exposing these two catalysts to acetylene and hydrogen after reduction at $350{ }^{\circ} \mathrm{C}$. We found that two negative peaks at 3562 and $3430 \mathrm{~cm}^{-1}$ on $\mathrm{Ni}_{1} / \mathrm{g}-\mathrm{C}_{3} \mathrm{~N}_{4}$, assigned to $\mathrm{Ni}-\mathrm{OH}$ groups ${ }^{49}$, developed with time as exposing to acetylene at $160{ }^{\circ} \mathrm{C}$ (Fig. 3a). The consumption of hydroxyls may be attributed to their reaction with acetylene and $\mathrm{Ni}$ aggregations to $\mathrm{Ni} / \mathrm{NiO}_{x}$ particles (Supplementary Figs. 20 and 26). Meanwhile, the IR bands in the ranges of 3200-3300, 2900-3200 and $2800-2900 \mathrm{~cm}^{-1}$ gradually increased in intensity with time, which are assigned to the $\mathrm{v}(\mathrm{\equiv} \mathrm{C}-\mathrm{H})$ vibrations of gas phase acetylene, $\mathrm{v}(\mathrm{C}-\mathrm{H})$ of chemisorbed acetylene, and $\mathrm{v}\left(\mathrm{CH}_{3}\right)$ of ethylidene/ethylidyne, respectively ${ }^{50}$. Next, switching the gas to hydrogen declined the peaks of all $\mathrm{C}-\mathrm{H}$ stretching, indicating the formation of ethylene and ethane. However, the $\mathrm{Ni}-\mathrm{OH}$ groups were not recovered. Repeating the above experiments for another acetylenehydrogen cycle showed a similar result, but we noticed that the $\mathrm{v}\left(\mathrm{CH}_{3}\right)$ of ethylidene/ethylidyne peak intensity became more pronounced during the initial $\mathrm{H}_{2}$ exposure in the second cycle, suggesting more ethane was formed in the second acetylene-hydrogen cycle.

In the case of $\mathrm{Ni}_{1} \mathrm{Cu}_{2} / \mathrm{g}^{-} \mathrm{C}_{3} \mathrm{~N}_{4}$, two negative peaks at 3595 and $3453 \mathrm{~cm}^{-1}$ of $\mathrm{Ni}-\mathrm{OH}$, along with positive $\mathrm{v}(\equiv \mathrm{C}-\mathrm{H})$ vibrations of gas phase acetylene $\left(3200-3300 \mathrm{~cm}^{-1}\right), \mathrm{v}(\mathrm{C}-\mathrm{H})$ of chemisorbed acetylene (2900$3200 \mathrm{~cm}^{-1}$ ), emerged as exposing to acetylene at $160{ }^{\circ} \mathrm{C}$ (Fig. 3b). Next, switching the gas to hydrogen recovered the $\mathrm{Ni}-\mathrm{OH}$ group, and declined all $\mathrm{C}-\mathrm{H}$ stretching. Repeating the experiments for another acetylene-hydrogen cycle showed identical results. Consumption and regeneration of $\mathrm{Ni}-\mathrm{OH}$ groups during sequential acetylene and hydrogen exposures is in sharp contrast with that of $\mathrm{Ni}_{1} / \mathrm{g}-\mathrm{C}_{3} \mathrm{~N}_{4}$, implying that $\mathrm{Ni}-\mathrm{OH}$ group is present in $\mathrm{Ni}_{1} \mathrm{Cu}_{2} / \mathrm{g}-\mathrm{C}_{3} \mathrm{~N}_{4}$, and participates into the hydrogenation reaction. Interestingly, we noticed that there was lack of any features in the range of $2800-2900 \mathrm{~cm}^{-1}$, suggesting that much less ethane was formed on $\mathrm{Ni}_{1} \mathrm{Cu}_{2} / \mathrm{g}-\mathrm{C}_{3} \mathrm{~N}_{4}$, in an excellent agreement with the high ethylene selectivity as shown in Fig. 1b. 
Theoretical insight of $\mathrm{Ni}_{1}$ and $\mathrm{Ni}_{1} \mathrm{Cu}_{2}$ catalysts. Based on the above structural characterization and extensive DFT calculations, the NiCu complexes on $\mathrm{g}-\mathrm{C}_{3} \mathrm{~N}_{4}$ is identified as a chain-like $\mathrm{Cu}-\mathrm{OH}-\mathrm{Ni}-\mathrm{OH}-\mathrm{Cu}$ structure (Fig. $4 \mathrm{a}$ and Supplementary Fig. 30 ), whereas the Ni spices in $\mathrm{Ni}_{1} / \mathrm{g}-\mathrm{C}_{3} \mathrm{~N}_{4}$ after reduction is $\mathrm{Ni}_{1}(\mathrm{OH})_{2}$ complexes (Supplementary Fig. 31 and Supplementary Table 9). For the former one, the Ni atom bonds to $\mathrm{N}_{\mathrm{py}}$ and $\mathrm{C}$ of $\mathrm{g}-\mathrm{C}_{3} \mathrm{~N}_{4}$ underneath, confined by $\mathrm{Cu}$ atom from two sides through bridging $\mathrm{OH}$ group; the $\mathrm{Cu}$ atom grippers are further fastened on $\mathrm{g}-\mathrm{C}_{3} \mathrm{~N}_{4}$ through strong $\mathrm{Cu}-\mathrm{N}_{\mathrm{py}}$ bond. Optimized bond lengths of the $\mathrm{Ni}-\mathrm{O} / \mathrm{N} / \mathrm{C}$ bond and $\mathrm{Cu}-\mathrm{O} / \mathrm{N}$ bond are an average of 1.95 and $1.87 \AA$ with corresponding CNs of 4 and 2 (Supplementary Table 10), respectively, in excellent agreement with EXAFS. The overall length of the optimized complexes (5.84 $\AA$ ) and two unequal Ni-Cu distances (2.74 and $3.10 \AA$ ) also agree perfectly with STEM (Fig. 2C). Charge density difference shows that there is significant charge accumulation between the $\mathrm{Ni}-\mathrm{C} / \mathrm{N}$ bonds and between the $\mathrm{Cu}-\mathrm{C} / \mathrm{N}$ bonds, while considerable charge transferring from Ni/Cu to high-lying $\mathrm{OH}$ groups (Fig. 4a and Supplementary Fig. 32). Simultaneous presence of characteristic covalent bond and ionic bond manifest clearly the so-called SMSI between $\mathrm{Ni}_{1} \mathrm{Cu}_{2}(\mathrm{OH})_{2}$ and g- $\mathrm{C}_{3} \mathrm{~N}_{4}$ support, which was found in $\mathrm{Ni}_{1}(\mathrm{OH})_{2} / \mathrm{g}-\mathrm{C}_{3} \mathrm{~N}_{4}$ as well.

As shown above, $\mathrm{Ni}_{1} / \mathrm{g}-\mathrm{C}_{3} \mathrm{~N}_{4}$ and $\mathrm{Ni}_{1} \mathrm{Cu}_{2} / \mathrm{g}-\mathrm{C}_{3} \mathrm{~N}_{4}$ exhibited sharply different chemical stability under the hydrogenation condition, although both are stable in $\mathrm{H}_{2}$. Different chemical stability after introduction of acetylene and ethylene stems from the distinct structure change induced by their stronger adsorption to both $\mathrm{Ni}_{1} / \mathrm{g}-\mathrm{C}_{3} \mathrm{~N}_{4}$ and $\mathrm{Ni}_{1} \mathrm{Cu}_{2} / \mathrm{g}-\mathrm{C}_{3} \mathrm{~N}_{4}$ than $\mathrm{H}_{2}$, as found by DFT calculations and the corresponding TPD measurement (Supplementary Fig. 33 and Supplementary Table 11). It is found that acetylene adsorption on $\mathrm{Ni}_{1} / \mathrm{g}-\mathrm{C}_{3} \mathrm{~N}_{4}$ goes through a modest barrier of $0.62 \mathrm{eV}$ with an exothermic adsorption energy of $0.69 \mathrm{eV}$ (Fig. 4b). At the meanwhile, one Ni-N/C support bond is broken, and there is only one Ni-N/C support bond left between the $\mathrm{Ni}(\mathrm{OH})_{2}-\mathrm{C}_{2} \mathrm{H}_{2}$ complex and the $\mathrm{g}-\mathrm{C}_{3} \mathrm{~N}_{4}$ support underneath, which can be broken further with a barrier of $0.66 \mathrm{eV}$ only. In other words, the $\mathrm{Ni}(\mathrm{OH})_{2}-\mathrm{C}_{2} \mathrm{H}_{2}$ complex formed is rather mobile on $\mathrm{Ni}_{1} / \mathrm{g}$ $\mathrm{C}_{3} \mathrm{~N}_{4}$, and this would facilitate its aggregation and subsequent formation of Ni NPs, as found by STEM and XPS in acetylene hydrogenation (Supplementary Figs. 20 and 26). The formed Ni particles, owing to the presence of large Ni assembles, in turn dramatically promotes the heavy coke formation (Fig. 1e-g), thus endowing rapid catalyst deactivation to a short catalyst life time (Fig. 1d). Obviously, SMSI alone is not sufficient to stabilize the $\mathrm{Ni}(\mathrm{OH})_{2}$ complexes, although the corresponding bonding by the two Ni-N bonds $(-2.93 \mathrm{eV})$ is considerable strong.

Acetylene adsorption on $\mathrm{Ni}_{1} \mathrm{Cu}_{2} / \mathrm{g}-\mathrm{C}_{3} \mathrm{~N}_{4}$ is stronger with an exothermic energy of $1.00 \mathrm{eV}$ from $\mathrm{DFT}$, and corresponding TPD measurement indeed found a higher desorption temperature than that on $\mathrm{Ni}_{1} / \mathrm{g}-\mathrm{C}_{3} \mathrm{~N}_{4}$ (Supplementary Fig. 33). Optimized structure indicates that though acetylene adsorption breaks two interfacial Ni-N/C support bonds with practically no barrier, there are two new Ni-C bonds with adsorbed $\mathrm{C}_{2} \mathrm{H}_{2}$ formed (Fig. $4 \mathrm{~b}$ and Supplementary Video 1 ). As a result, the overall coordination number of the $\mathrm{Ni}$ atom before and after acetylene adsorption does not change, a fact of that agrees excellently with invariant XAFS curve in both acetylene hydrogenation and pure hydrogen conditions (Fig. 2e, and Supplementary Table 10). Nonetheless, spatial confinement by the two atomic Cu grippers from both 
sides through two bridging hydroxyls endows the breakages of $\mathrm{Cu}-\mathrm{O}$ support bond extremely endothermic by more than $4 \mathrm{eV}$, ensuring a high chemical stability of this catalyst during acetylene hydrogenation. Resulted dynamics of the Ni atoms from synergizing SMSI and spatial confinements ensures not only a facile structural transformation by breaking the Ni-N/C bonds to enhance the adsorption of acetylene, but also a high chemical/thermal stability of SADCs free from aggregation (Supplementary Fig. 34).

Atomically dispersed and stable $\mathrm{Ni}$ atoms is beneficial to suppress the $\mathrm{C}-\mathrm{C}$ bond breaking and making necessarily for formation of graphitic coke and green oils due to the limited sites available (Fig. 4c, and Supplementary Table 12). For instance, cleavage of adsorbed acetylene is highly endothermic because of the absence of sites accommodating the broken $\mathrm{CH}^{*}$ fragments. Moreover, after adsorption of acetylene preferentially at the top of the $\mathrm{Ni}$ atom, additional adsorption of acetylene or ethylene is only possible at the Cu sites with a weak binding energy of -0.55 and $-0.51 \mathrm{eV}$, respectively, but will desorb at temperatures above room temperature (RT). As a result, formation of graphitic coke and green oils is prohibited on $\mathrm{Ni}_{1} \mathrm{Cu}_{2} / \mathrm{g}-\mathrm{C}_{3} \mathrm{~N}_{4}$, in an excellent agreement with the in situ SVUV-PIMS and TGA measurements (Fig. 1e-g).

Beside high stability and high coking-resistance, characteristic dynamics of Ni atoms from SMSI and spatial confinement also renders this material with high activity and selectivity (Supplementary Fig. 34 and Supplementary Video 1). Optimized potential energy surfaces for hydrogenation of acetylene over the $\mathrm{Ni}_{1}(\mathrm{OH})_{2} \mathrm{Cu}_{2}$ complex are shown in Fig. $4 \mathrm{~d}$ (also seen the details in Supplementary Figs. 35-37). Acetylene is expected to be dominant on the Ni sites during hydrogenation, because acetylene $(-1.00 \mathrm{eV})$ adsorption on the Ni site is much stronger than that of $\mathrm{H}_{2}(-0.07 \mathrm{eV})$ (Supplementary Fig. 33, and Supplementary Table 11). After acetylene adsorption, the proton in one bridging $\mathrm{OH}$ tends to attack the adsorbed acetylene directly with a barrier of $1.23 \mathrm{eV}$ to form $\mathrm{C}_{2} \mathrm{H}_{3}$ * (here * denotes surface species, Fig. $4 \mathrm{~d}$, $\mathrm{i}$ and ii). Next, hydrogen adsorbs on the $\mathrm{Ni}$ sites and dissociates effortlessly with one $\mathrm{H}$ atom addition to $\mathrm{C}_{2} \mathrm{H}_{3}{ }^{*}$ to form $\mathrm{C}_{2} \mathrm{H}_{4}{ }^{*}$, and the other one bonding to the Ni site (Fig. 4 d, iii and iv). After that, the $\mathrm{C}_{2} \mathrm{H}_{4}{ }^{*}$ specie rearranges and the $\mathrm{H}$ atom transfers to the bridging $\mathrm{O}$ from $\mathrm{Ni}$ to regenerate the bridging $\mathrm{OH}$ with a low barrier of $0.81 \mathrm{eV}$. Compared to the sequential high hydrogenation barrier of $1.38 \mathrm{eV}$ from ethylene to ethane, weakly bonded ethylene with a value of $-0.67 \mathrm{eV}$ boosts the desorption rate of ethylene, a key step for a high selectivity of $\mathrm{Ni}_{1} \mathrm{Cu}_{2} / \mathrm{g}-\mathrm{C}_{3} \mathrm{~N}_{4}$, in line with the catalytic results in Fig. 1 . Obviously, the bridging hydroxyls participation into the hydrogenation reaction suggested by DFT consists very well with the DRIFTS results (Fig. 3).

\section{Conclusions}

In summary, we have reported that synergizing SMSI and spatial confinement through the $\mathrm{Cu}$ atomic grippers boosts dynamics of high loaded atomic $\mathrm{Ni}$ on a g- $\mathrm{C}_{3} \mathrm{~N}_{4}$ support for efficient hydrogenations. Such dynamic and synergetic effects enable not only exceptionally high stability against both sintering and coke formation in hydrogenation of acetylene and 1,3-butadiene, but also lead the active sites highly adaptable for both reactant adsorption and product desorption, thus boosting an activity, 11 times higher 
than the conventional $\mathrm{Ni}_{1} / \mathrm{g}-\mathrm{C}_{3} \mathrm{~N}_{4}$ catalyst, and high ethylene selectivity. This is the first example of synthesis of dynamically confined SADCs using an atom-by-atom fabrication approach, shedding light on how rational design of highly-active and stable catalysts can achieve practical application in selective chemical reactions. This work might bridge and inspire the heterogeneous catalysis community and organometallic community to develop new structures of advanced catalysts for large-scale industrial processes in the near future.

\section{Methods}

Materials. Copper(II) hexafluoroacetylacetonate hydrate $\left(\mathrm{Cu}(\mathrm{hfac})_{2}\right)$, formalin $(37 \%$ formaldehyde in aqueous solution), and bis(cyclopentadienyl) nickel(II) $\left(\mathrm{NiCp}_{2}\right)$ were all bought from Shanghai Aladdin Bio-Chem Technology Co., Ltd. Urea (99\%), $\mathrm{Cu}_{2} \mathrm{O}$ (99.9\%), $\mathrm{Ni}\left(\mathrm{NO}_{3}\right)_{2} \cdot 6 \mathrm{H}_{2} \mathrm{O}(99 \%), \mathrm{NaBH}_{4}(99 \%), \mathrm{CuO}(99 \%)$, $\mathrm{CaCl}_{2}(99 \%)$ and $\mathrm{NiO}$ (99\%) were purchased from Sinopharm Chemical Reagent Co., Ltd. Nickel(II) phthalocyanine ( $\mathrm{NiPc}$ ), copper(II) phthalocyanine (CuPc), and $\mathrm{Ni} / \mathrm{SiO}_{2}-\mathrm{Al}_{2} \mathrm{O}_{3}$ catalyst (Ni loading 66 wt.\%) were all bought from Alfa Aesar Co., Ltd. Lindlar Pd catalyst ( $\left.\mathrm{Pd}-\mathrm{PbO} / \mathrm{CaCO}_{3}\right)$ was purchased from TCl (Shanghai) Development Co., Ltd. All chemicals were used as received without further purification.

Ultrahigh purity $\mathrm{N}_{2}(99.999 \%), \mathrm{O}_{2}(99.999 \%), \mathrm{H}_{2}(99.999 \%), \operatorname{Ar}(99.999 \%)$, and the gas mixtures include: $10 \% \mathrm{O}_{2}$ in $\mathrm{Ar}, 10 \% \mathrm{H}_{2}$ in $\mathrm{Ar}, 0.5 \% \mathrm{C}_{2} \mathrm{H}_{2}, 5 \% \mathrm{H}_{2}, 25 \% \mathrm{C}_{2} \mathrm{H}_{4}$ in $\mathrm{Ar}, 1.2 \%$ 1.3-butadiene, $12 \% \mathrm{H}_{2}$ in Ar were all provided by Nanjing Special Gases.

Synthesis of $\mathrm{g}-\mathrm{C}_{3} \mathrm{~N}_{4}$ support. Urea was placed in a crucible and heated to $600^{\circ} \mathrm{C}$ for $4 \mathrm{~h}$ in static air with a ramp rate of $5^{\circ} \mathrm{C} \mathrm{min}{ }^{-1}$. The resulting yellow material was milled into fine powders in a mortar. Next, the yellow powder was placed in an open ceramic container and heated at $550{ }^{\circ} \mathrm{C}$ for another $4 \mathrm{~h}$. A lightyellow powder of $\mathrm{g}-\mathrm{C}_{3} \mathrm{~N}_{4}$ support was finally obtained.

Synthesis of $\mathrm{Cu}_{1} / \mathrm{g}-\mathrm{C}_{3} \mathrm{~N}_{4}$ catalysts. Cu ALD was carried out on a viscous flow stainless steel tube reactor system (ACME (Beijing) Technology Co., Ltd) at $300^{\circ} \mathrm{C}$ using $\mathrm{Cu}(\mathrm{hfac})_{2}$ and formaldehyde as precursors. Ultrahigh purity $\mathrm{N}_{2}(99.999 \%)$ was used as a carrier gas at a flow rate of $60 \mathrm{~mL} \cdot \mathrm{min}^{-1}$. The $\mathrm{Cu}(\mathrm{hfac})_{2}$ precursor container was heated to $65^{\circ} \mathrm{C}$ to reach a sufficient vapor pressure. The inlet manifold was held at $100{ }^{\circ} \mathrm{C}$ to avoid precursor condensation. The timing sequence was $300,300,40$, and $180 \mathrm{~s}$ for $\mathrm{Cu}(\mathrm{hfac})_{2}$ exposure, $\mathrm{N}_{2}$ purge, formaldehyde exposure, and $\mathrm{N}_{2}$ purge, respectively. One, two, and ten cycles of $\mathrm{Cu}$ ALD were performed on g- $\mathrm{C}_{3} \mathrm{~N}_{4}$ to obtain $\mathrm{Cu}_{1}(5.1 \%) / g-\mathrm{C}_{3} \mathrm{~N}_{4}, \mathrm{Cu}_{1}(8.1 \%) / \mathrm{g}-\mathrm{C}_{3} \mathrm{~N}_{4}$, and $\mathrm{Cu}_{1}(11.4 \%) / \mathrm{g}-\mathrm{C}_{3} \mathrm{~N}_{4}$ catalysts, respectively. When the $\mathrm{Cu}(\mathrm{hfac})_{2}$ exposure time was reduced to $150 \mathrm{~s}$, one cycle of $\mathrm{Cu}$ ALD on $\mathrm{g}-\mathrm{C}_{3} \mathrm{~N}_{4}$, yielded a Cu loading of $2.7 \%$, which was denoted as $\mathrm{Cu}_{1}(2.7 \%) / \mathrm{g}-\mathrm{C}_{3} \mathrm{~N}_{4}$.

Synthesis of $\mathrm{Ni}_{1} / \mathrm{g}-\mathrm{C}_{3} \mathrm{~N}_{4}$ and $\mathrm{Ni}_{1} \mathrm{Cu}_{2} / \mathrm{g}-\mathrm{C}_{3} \mathrm{~N}_{4}$ catalysts. $\mathrm{NiO}_{x}$ ALD was carried out on the $\mathrm{g}-\mathrm{C}_{3} \mathrm{~N}_{4}$ support at $240{ }^{\circ} \mathrm{C}$ using $\mathrm{NiCp}_{2}$ and ozone as precursors. The $\mathrm{NiCp}_{2}$ precursor container was heated to $90^{\circ} \mathrm{C}$ to achieve a sufficient vapor pressure. The inlet manifold was held at $115^{\circ} \mathrm{C}$ to avoid precursor condensation on the inner walls. The timing sequence was $1260,200,1260$, and $200 \mathrm{~s}$ for the $\mathrm{NiCp}_{2}$ 
exposure, $\mathrm{N}_{2}$ purge, $\mathrm{O}_{3}$ exposure, and $\mathrm{N}_{2}$ purge, respectively. Different $\mathrm{NiCp}_{2}$ exposure time (from 100 to $1260 \mathrm{~s}$ ) was performed on $\mathrm{g}-\mathrm{C}_{3} \mathrm{~N}_{4}$ to obtain a series of Ni single-atom catalysts with different $\mathrm{Ni}$ loadings (denoted as $\mathrm{Ni}_{1}(x \%) / g-\mathrm{C}_{3} \mathrm{~N}_{4}, x$ is the Ni loading). $\mathrm{NiO}_{x}$ ALD was also carried on the $\mathrm{Cu}_{1}(5.1 \%) / g-\mathrm{C}_{3} \mathrm{~N}_{4}$ and $\mathrm{Cu}_{1}(8.1 \%) / \mathrm{g}-\mathrm{C}_{3} \mathrm{~N}_{4}$ samples. The resulting samples were denoted as $\mathrm{Ni}_{1} \mathrm{Cu}_{1} / \mathrm{g}-\mathrm{C}_{3} \mathrm{~N}_{4}$ and $\mathrm{Ni}_{1} \mathrm{Cu}_{2} / \mathrm{g}-\mathrm{C}_{3} \mathrm{~N}_{4}$, respectively.

Synthesis of $\mathrm{Ni}_{\mathrm{NPs}} / \mathrm{g}-\mathrm{C}_{3} \mathrm{~N}_{4}$ catalyst. The g- $\mathrm{C}_{3} \mathrm{~N}_{4}$ supported $\mathrm{Ni}$ particle catalyst $\left(\mathrm{Ni}_{\mathrm{NPs}} / \mathrm{g}-\mathrm{C}_{3} \mathrm{~N}_{4}\right)$ was synthesized using the precipitation deposition method. Briefly, 1 gram of as-prepared g- $\mathrm{C}_{3} \mathrm{~N}_{4}$ support was immersed into $50 \mathrm{~mL}$ water, then stirring for $10 \mathrm{~min}$ at room temperature. $\mathrm{Next}, 198 \mathrm{mg}$ of Ni(NO$\left.)_{3}\right)_{2} \cdot 6 \mathrm{H}_{2} \mathrm{O}$ was slowly added into the solution and stirred for $1 \mathrm{~h}$, Afterward, an aqueous solution of $\mathrm{NaBH}_{4}(0.54 \mathrm{~mol}$ $\mathrm{L}^{-1}, 10 \mathrm{~mL}$ ) was added dropwise and stirred overnight. The solids were separated by filtration, washed thoroughly with $\mathrm{H}_{2} \mathrm{O}$ and dried overnight at $70{ }^{\circ} \mathrm{C}$. Finally, the dried material was reduced at $350{ }^{\circ} \mathrm{C}$ for $2 \mathrm{~h}$ in $10 \% \mathrm{H}_{2} /$ Ar to obtain the $\mathrm{Ni}_{\mathrm{NPs}} / \mathrm{g}-\mathrm{C}_{3} \mathrm{~N}_{4}$ catalyst.

Morphology and compositions. Aberration-corrected high-angle annular dark-field scanning transmission electron microscopy (HAADF-STEM) measurements were taken on a JEM-ARM200F instrument (University of Science and Technology of China) at $200 \mathrm{keV}$. Meanwhile, energy-dispersive X-ray elemental mapping was also collected on the same equipment. Transmission electron microscopy (TEM) and STEM measurements were performed on another JEOL-2100F instrument operated at $200 \mathrm{keV}$. The $\mathrm{Ni}$ and $\mathrm{Cu}$ loadings of the catalysts were analyzed by an inductively coupled plasma atomic emission spectrometer (ICP-AES). X-ray diffraction (XRD) spectra were recorded on a SmartLab ${ }^{\mathrm{TM}} 9 \mathrm{kw}$ Rotating Anode X-ray diffractometer.

In situ SVUV-PIMS Measurements. To study the formation of green oils, in situ SVUV-PIMS measurements were conducted on the mass spectrometry end-station (BL04B) of the National Synchrotron Radiation Laboratory, Hefei, China ${ }^{51}$. In brief, $150 \mathrm{mg}$ of $\mathrm{Ni}_{1} \mathrm{Cu}_{2} / \mathrm{g}-\mathrm{C}_{3} \mathrm{~N}_{4}$ or $\mathrm{Ni}_{1} / \mathrm{g}-\mathrm{C}_{3} \mathrm{~N}_{4}$ catalyst was loaded in a fixed-bed flow reactor, which was connected to the SVUV-PIMS system ${ }^{52}$. The catalyst was first reduced in $10 \% \mathrm{H}_{2}$ in Ar at a flow rate of $50 \mathrm{~mL} \mathrm{~min}^{-1}$ at $350^{\circ} \mathrm{C}$ for $2 \mathrm{~h}$, then cooled to $160{ }^{\circ} \mathrm{C}$ for $\mathrm{Ni}_{1} \mathrm{Cu}_{2} / \mathrm{g}-\mathrm{C}_{3} \mathrm{~N}_{4}$ and $200^{\circ} \mathrm{C}$ for $\mathrm{Ni}_{1} / \mathrm{g}-\mathrm{C}_{3} \mathrm{~N}_{4}$. After the sample temperature became stabilized, reaction gas consisting of $0.5 \% \mathrm{C}_{2} \mathrm{H}_{2}, 5 \% \mathrm{H}_{2}$, and $25 \% \mathrm{C}_{2} \mathrm{H}_{4}$ balanced with $\mathrm{Ar}$ at a flow rate of $50 \mathrm{~mL} \mathrm{~min}^{-1}$ was then introduced to the quartz-tube reactor at a total pressure of 2 Torr. The volatile components at the reactor outlet were ionized by the synchrotron VUV light, and the formed ions were analyzed by a homemade time-of-flight mass spectrometer at a photon energy of $12 \mathrm{eV}$. After $2 \mathrm{~h}$ of continuous data collection, the reaction gas was switched to pure Ar, then gradually increasing the sample temperature at a heating rate of $5^{\circ} \mathrm{C} \mathrm{min}-1$ to $300^{\circ} \mathrm{C}$, while the composition of accumulated green oils on two samples were analyzed by the online SVUV-PIMS spectrometer.

In situ TGA measurements. In situ TGA measurements were performed on a TGA550 instrument (TA instruments) equipped with an evolved gas analysis (EGA) furnace to quantify the coke formation during 
semi-hydrogenation of acetylene. After loading sample into the EGA furnace, the sample was heated to $350^{\circ} \mathrm{C}$ with a heating rate of $3{ }^{\circ} \mathrm{C} \mathrm{min}^{-1}$ in $10 \% \mathrm{H}_{2} / \mathrm{Ar}\left(25 \mathrm{~mL} \mathrm{~min}{ }^{-1}\right)$ and then maintained isothermally for $2 \mathrm{~h}$ to reduce the sample. Next, the sample was cooled to a specified temperature in argon $\left(25 \mathrm{~mL} \mathrm{~min}^{-1}\right)$ and maintained isothermally for $1 \mathrm{~h}$ to stabilize the instrument. Next, acetylene hydrogenation gases consisting of $0.5 \%$ acetylene, $5 \% \mathrm{H}_{2}$, and $25 \%$ ethylene balanced in Ar was introduced to the sample at a flow rate of $25 \mathrm{~mL} \mathrm{~min}^{-1}$ for about $12 \mathrm{~h}$ at the specified temperature. The change of the sample weight with time during acetylene hydrogenation was recorded. Here the temperatures for acetylene hydrogenation were 160 , and $200^{\circ} \mathrm{C}$, for $\mathrm{Ni}_{1} \mathrm{Cu}_{2} / \mathrm{g}-\mathrm{C}_{3} \mathrm{~N}_{4}$, and $\mathrm{Ni}_{1} / \mathrm{g}-\mathrm{C}_{3} \mathrm{~N}_{4}$ catalysts, respectively, to ensure a similar initial conversion for these samples.

In situ XPS measurements. In situ XPS and Auger spectra measurements were conducted at the BL10B beamline photoemission end station at the National Synchrotron Radiation Laboratory (NSRL) in Hefei, China. In brief, the beamline is connected to a bending magnet and covers photon energies from 100 to $1000 \mathrm{eV}$. The end-station consists of four chambers, i.e., analysis chamber, preparation chamber, quick sample load-lock chamber and a high-pressure reactor. The analysis chamber, with a base pressure of $<5 \times 10^{-10}$ torr, is connected to the beamline and equipped with a VG Scienta R3000 electron energy analyzer and a twin anode $\mathrm{X}$-ray source. The high-pressure reactor houses a reaction cell where the samples can be treated with different gases up to 20 bar and simultaneously heated up to $650^{\circ} \mathrm{C}$. After sample treatment, the reactor can be pumped down to high vacuum $\left(<10^{-8}\right.$ torr $)$ for sample transfer.

In this work, after loading the as-prepared $\mathrm{Ni}_{1} \mathrm{Cu}_{2} / \mathrm{g}-\mathrm{C}_{3} \mathrm{~N}_{4}$ sample into the chamber, a set of XPS spectra in the $\mathrm{Ni} 2 \mathrm{p}, \mathrm{Cu} 2 \mathrm{p}, \mathrm{N} \mathrm{1s}, \mathrm{C} 1 \mathrm{~s}$, and $\mathrm{O} 1 \mathrm{~s}$ regions were first recorded without any treatment (denoted as $\mathrm{Ni}_{1} \mathrm{Cu}_{2} / \mathrm{g}-\mathrm{C}_{3} \mathrm{~N}_{4}$ ). Next, the sample was transferred back into the high-pressure reactor, and reduced in $10 \%$ $\mathrm{H}_{2}$ in $\mathrm{Ar}$ at $350^{\circ} \mathrm{C}$ for $2 \mathrm{~h}$ at the atmosphere pressure. Another set of XPS spectra were collected after transferred back to the analysis chamber. The reduced sample was denoted as $\mathrm{Ni}_{1} \mathrm{Cu}_{2} / \mathrm{g}-\mathrm{C}_{3} \mathrm{~N}_{4}-\mathrm{R}$. Finally, the sample was exposed to the acetylene hydrogenation stream consisting $0.5 \% \mathrm{C}_{2} \mathrm{H}_{2}, 5 \% \mathrm{H}_{2}$, and $25 \%$ $\mathrm{C}_{2} \mathrm{H}_{4}$ balanced with $\mathrm{Ar}$ in the high-pressure reactor at $160^{\circ} \mathrm{C}$ for another $1 \mathrm{~h}$. Another set of XPS spectra were then collected after the hydrogenation reaction gas treatment without exposing to air, which was denoted as $\mathrm{Ni}_{1} \mathrm{Cu}_{2} / \mathrm{g}-\mathrm{C}_{3} \mathrm{~N}_{4}-\mathrm{H}$. Similarly, XPS spectra of the $\mathrm{Ni}_{1} / \mathrm{g}-\mathrm{C}_{3} \mathrm{~N}_{4}$ sample were also collected following the same procedure. The XPS spectra of the sample after reduction at $350{ }^{\circ} \mathrm{C}$ for $2 \mathrm{~h}$ and exposing reaction gas at $200{ }^{\circ} \mathrm{C}$ for another $1 \mathrm{~h}$ were denoated as $\mathrm{Ni}_{1} / \mathrm{g}-\mathrm{C}_{3} \mathrm{~N}_{4}-\mathrm{R}$ and $\mathrm{Ni}_{1} / \mathrm{g}-\mathrm{C}_{3} \mathrm{~N}_{4}-\mathrm{H}$, respectively. The $\mathrm{C} 1 \mathrm{~s}$ binding energy at $284.8 \mathrm{eV}$ was used as an internal reference.

In situ XAFS. In situ XAFS measurements at the Ni K edge (8333 eV) and the Cu K edge (8979 eV) were performed in a transmission mode with the Si(311) monochromator at the BL14W1 beamline of the Shanghai Synchrotron Radiation Facility (SSRF), China. The storage ring of SSRF worked at $3.5 \mathrm{GeV}$ with a maximum current of $210 \mathrm{~mA}^{53}$. A homemade reaction cell was used for the operando experiments, which allows exposing the sample to different pretreatment gases or reactions gases, as well as sample heating up to $400^{\circ} \mathrm{C}$. 
Typically, the as-prepared $\mathrm{Ni}_{1} \mathrm{Cu}_{2} / \mathrm{g}-\mathrm{C}_{3} \mathrm{~N}_{4}$ sample was put into the reaction cell and purged with $\mathrm{He}$ for 10 $\mathrm{min}$ at room temperature, then XAFS spectra were recorded at both the $\mathrm{Ni}$ and $\mathrm{Cu} \mathrm{K}$ edges (denoted as $\mathrm{Ni}_{1} \mathrm{Cu}_{2} / \mathrm{g}-\mathrm{C}_{3} \mathrm{~N}_{4}$ ). After that, the sample was reduced in $10 \% \mathrm{H}_{2}$ in $\mathrm{He}$ at $350{ }^{\circ} \mathrm{C}$ for $2 \mathrm{~h}$. After cooling the sample to $160^{\circ} \mathrm{C}$ in $10 \% \mathrm{H}_{2}$ in $\mathrm{He}$, a XAFS spectrum was recorded at the $\mathrm{Ni} \mathrm{K}$ edge and $\mathrm{Cu} \mathrm{K}$ edge, which was denoted as $\mathrm{Ni}_{1} \mathrm{Cu}_{2} / \mathrm{g}-\mathrm{C}_{3} \mathrm{~N}_{4}-\mathrm{R}$. Finally, the sample was exposed to the acetylene hydrogenation reaction stream consisting $0.5 \% \mathrm{C}_{2} \mathrm{H}_{2}, 5 \% \mathrm{H}_{2}$, and $25 \% \mathrm{C}_{2} \mathrm{H}_{4}$ balanced with Ar at $160{ }^{\circ} \mathrm{C}$ for another $1 \mathrm{~h}$, and XAFS spectra were recorded sequentially at the $\mathrm{Ni}$ and $\mathrm{Cu} \mathrm{K}$ edges, which were denoted as $\mathrm{Ni}_{1} \mathrm{Cu}_{2} / \mathrm{g}$ $\mathrm{C}_{3} \mathrm{~N}_{4}-\mathrm{H}$. Similarly, in situ XAFS measurements of $\mathrm{Ni}_{1} / \mathrm{g}-\mathrm{C}_{3} \mathrm{~N}_{4}$ were also collected following the same procedure but only collecting XAFS spectra at the Ni K edge. The XAFS spectra of the sample after reduction at $350^{\circ} \mathrm{C}$ for $2 \mathrm{~h}$ was denoated as $\mathrm{Ni}_{1} / \mathrm{g}-\mathrm{C}_{3} \mathrm{~N}_{4}-\mathrm{R}$.

The acquired EXAFS data were processed according to the standard procedures using the ARTEMIS module implemented in the IFEFFIT software packages. The EXAFS oscillation functions $\chi(k)$ were obtained by subtracting the post-edge background from the overall absorption spectra and then normalized with respect to the edge-jump step.

In terms of the Ni K edge, fittings were done in the $R$-space within the $R$-range of $0.8-3.0 \AA^{-1}$ for $k^{3}-$ weighted $\chi(k)$ functions with Hanning windows $\left(d k=1.0 \AA^{-1}\right)$, and a $k$-range of $2.3-10.4 \AA^{-1}$ was used, during curve fittings, the amplitude reduction factor $S_{0}{ }^{2}$ was fixed at the value of 0.78 determined by fitting the data of $\mathrm{Ni}$ foil. In terms of the Cu K edge, the $R$-range of $1.1-3.0 \AA^{-1}$ and $k$-range of $2.9-12.4 \AA^{-1}$ were used, during curve fittings, the amplitude reduction factor $S_{0}{ }^{2}$ was fixed at the value of 0.9 determined by fitting the data of Cu foil. Debye-Waller factors $\left(\mathrm{s}^{2}\right)$, coordination numbers $(M)$ and interatomic distances $(R)$, energy shift $\left(D E_{0}\right)$ were treated as adjustable parameters during the fitting process.

The yielded $R$-factors of all samples are not larger than 0.008 , indicating the good fitting qualities.

Temperature-programmed desorption (TPD). The $\mathrm{H}_{2}, \mathrm{C}_{2} \mathrm{H}_{2}$ and $\mathrm{C}_{2} \mathrm{H}_{4}$ TPD experiments were performed on a micromeritics AutoChem II chemisorption analyzer, which was connected to a Pfeiffer OminiSTAR mass spectrometer. In a typical experiment, $50 \mathrm{mg}$ sample was first reduced in $10 \% \mathrm{H}_{2} / \mathrm{He}$ at $350{ }^{\circ} \mathrm{C}$ for $2 \mathrm{~h}$ and then purged with He at $300{ }^{\circ} \mathrm{C}$ for $1 \mathrm{~h}$. Next, the sample was cooled down to room temperature (RT) in He, $\mathrm{H}_{2}, \mathrm{C}_{2} \mathrm{H}_{2}$ or $\mathrm{C}_{2} \mathrm{H}_{4}$ gas was then introduced to the sample until saturation. Next, purging the sample with He at $25^{\circ} \mathrm{C}$ for $1 \mathrm{~h}$, then gradually increasing the sample temperature at a heating rate of $10^{\circ} \mathrm{C} \mathrm{min}{ }^{-1}$ in He from 25 to $300^{\circ} \mathrm{C}$, while recording the TPD data.

In situ DRIFTS. In situ DRIFTS were performed on a Thermo Nicolet iS10 FTIR spectrometer equipped with MCT detector at a resolution of $4 \mathrm{~cm}^{-1}$ and 128 scans. $30 \mathrm{mg}$ sample was first placed in a hightemperature cell (Harrick) with $\mathrm{CaF}_{2}$ windows. The sample was first reduced in $10 \% \mathrm{H}_{2}$ in $\mathrm{Ar}$ at $350{ }^{\circ} \mathrm{C}$ for $2 \mathrm{~h}$. Then the sample was cooled down to $160^{\circ} \mathrm{C}$. After that, the sample was exposed to $0.5 \% \mathrm{C}_{2} \mathrm{H}_{2} / \mathrm{Ar}$ 
$\left(30 \mathrm{~mL} \mathrm{~min}^{-1}\right)$ for $30 \mathrm{~min}$ and the spectra were collected continuously during this process. Next, the gas was switched to $10 \% \mathrm{H}_{2}$ in Ar for $30 \mathrm{~min}$, while recording the spectra. After that, the above experiments were repeated by sequentially exposing to $\mathrm{C}_{2} \mathrm{H}_{2}$ and $\mathrm{H}_{2}$. It should be noted that all gases were passed through a calcium chloride filter at $-40^{\circ} \mathrm{C}$ in the gas inlet line before the Harrick cell to remove the trace water from the gas.

Catalytic activity test. Selective hydrogenation of acetylene in excess ethylene was conducted in a fixedbed flow reactor. The total flow rate was kept at $30 \mathrm{~mL} \mathrm{~min}^{-1}$. The amount of non-precious catalyst was $150 \mathrm{mg}$, which was diluted with $1 \mathrm{~g}$ of 200 mesh quartz chips. Prior to the reaction test, all catalysts were reduced in $10 \% \mathrm{H}_{2}$ in $\mathrm{Ar}$ at $350^{\circ} \mathrm{C}$ for $2 \mathrm{~h}$. Then the feed gas, consisting of $0.5 \%$ acetylene, $5 \% \mathrm{H}_{2}$, and $25 \%$ ethylene with Ar as the balance gas, was introduced to the reactor to start the reaction. Next, the acetylene conversion of all these catalysts was increased by increasing the reaction temperature. The reaction products were analyzed using an online gas chromatograph (A91, PANNA Instruments) equipped with a flame ionization detector and a capillary column (ValcoPLOT VP-Alumina-KCl, $50 \mathrm{~m} \times 0.53 \mathrm{~mm}$ ). The acetylene conversion and ethylene selectivity were calculated using the following equations (1) and (2), respectively:

$$
\begin{aligned}
& \mathrm{C}_{2} \mathrm{H}_{2} \text { conversion }(\%)=\left(\frac{[\mathrm{C} 2 \mathrm{H} 2]_{\text {in }}-[\mathrm{c} 2 \mathrm{H} 2]_{\text {out }}}{[\mathrm{C} 2 \mathrm{H} 2]_{\text {in }}}\right) \times 100 \\
& \mathrm{C}_{2} \mathrm{H}_{4} \text { selectivity }(\%)=\left(1-\frac{[\mathrm{C} 2 \mathrm{H} 6]_{\text {out }}+2[\mathrm{C} 4]_{\text {out }}}{[\mathrm{C} 2 \mathrm{H} 2]_{\text {in }}-[\mathrm{C} 2 \mathrm{H} 2]_{\text {out }}}\right) \times 100
\end{aligned}
$$

$\left[\mathrm{C}_{2} \mathrm{H}_{2}\right]_{\text {in }}$ and $\left[\mathrm{C}_{2} \mathrm{H}_{2}\right]_{\text {out }}$ are the concentrations of acetylene at the inlet and outlet of reactor, respectively. $\left[\mathrm{C}_{2} \mathrm{H}_{6}\right]_{\text {out }}$ and $\left[\mathrm{C}_{4}\right]_{\text {out }}$ is the concentrations of ethane and total $\mathrm{C}_{4}$ products at the outlet of the reactor.

For the kinetic measurements, we reduced the amount of catalyst and increased the flow rate of reaction gas to ensure that the acetylene conversion was below $15 \%$. TOFs of the non-precious catalysts were calculated using the following equation (3):

$\mathrm{TOFs}=\frac{\text { Mole of } \mathrm{C} 2 \mathrm{H} 2 \text { converted per hour }}{\mathrm{D} \times n_{\text {metal }}}$

Here, $\mathrm{n}_{\text {metal }}$ is the mole of $\mathrm{Ni}$ or $\mathrm{Cu}$. For $\mathrm{Ni}_{1} \mathrm{Cu}_{2} / \mathrm{g}-\mathrm{C}_{3} \mathrm{~N}_{4}, \mathrm{n}_{\text {metal }}$ is the mole of Ni. D is the dispersion of metal nanoparticles or clusters/atoms, which is one for $\mathrm{Ni}_{1} / \mathrm{g}-\mathrm{C}_{3} \mathrm{~N}_{4}, \mathrm{Cu}_{1} / \mathrm{g}-\mathrm{C}_{3} \mathrm{~N}_{4}$, and $\mathrm{Ni}_{1} \mathrm{Cu}_{2} / \mathrm{g}-\mathrm{C}_{3} \mathrm{~N}_{4}$.

Semi-hydrogenation of 1.3-butadiene was also recorded on the same reaction test station and using the same gas chromatograph. The feed gas consists of 1.2\% 1,3-butadiene, $12 \% \mathrm{H}_{2}$ with $\mathrm{Ar}$ as balance gas. Same pretreatment was performed on all catalysts prior to the reaction test. The 1,3-butadiene conversion and butenes selectivity were calculated using the following equations (4) and (5), respectively: 
1,3 -butadiene conversion $(\%)=\frac{[1,3 \text {-butadiene }]_{\text {in }}-[1,3 \text {-butadiene }]_{\text {out }}}{[1,3-\text { butadiene }]_{\text {in }}} \times 100$

Butenes selectivity $(\%)=\frac{[\text { Butenes }]_{\text {out }}}{[\text { Butenes }]_{\text {out }}+[\text { Butane }]_{\text {out }}} \times 100$

[1,3-butadiene $]_{\text {in }}$ and [1,3-butadiene $]_{\text {out }}$ are the concentrations of 1,3-butadiene at the inlet and outlet of reactor. [Butenes] $]_{\text {out }}$ and [Butane $]_{\text {out }}$ are the concentrations of butenes and butane at the outlet of reactor, respectively.

Computational methods and models. All the spin-polarized calculations were performed using the DFT calculations as implemented in the Vienna ab initio Simulation Package (VASP) ${ }^{54}$. We described the electron-ion interaction using the projector augmented wave (PAW) method ${ }^{55}$. The exchange-correlation interaction was described by the optB86b-vdW functional ${ }^{56}$. The Kohn-Shame equations were solved by using a plane-wave basis set with a kinetic energy cutoff of $400 \mathrm{eV}$. The convergence criteria for electronic self-consistent interactions is $10^{-4} \mathrm{eV}$. The geometries of bulk and surface were optimized by the conjugate gradient algorithm until the maximum force on any ion was less than $0.02 \mathrm{eV} / \AA$. All the transition states were determined by using the climbing image nudged elastic band (Cl-NEB) method ${ }^{57}$ with confirmation of vibrational analysis. The transition states are optimized until all forces are below $0.05 \mathrm{eV} / \AA$.

The $\mathrm{g}-\mathrm{C}_{3} \mathrm{~N}_{4}$ was modelled by a $(2 \times 2)$ supercell of a single layer $\mathrm{g}-\mathrm{C}_{3} \mathrm{~N}_{4}$, where all the atoms in the supercell were fully relaxed. A $(3 \times 3 \times 1)$ Monkhorst-Pack k-point mesh was used to sample the surface Brillouin zone. A $20 \AA$ vacuum was introduced to avoid interaction from adjacent cells. The reaction energy and barrier are calculated by $\Delta \mathrm{E}=\mathrm{E}_{\mathrm{FS}}-\mathrm{E}_{\mathrm{IS}}$ and $\mathrm{E}_{\mathrm{a}}=\mathrm{E}_{\mathrm{TS}}-\mathrm{E}_{\mathrm{IS}}$, where $\mathrm{E}_{\mathrm{IS}}, \mathrm{E}_{\mathrm{FS}}$, and $\mathrm{E}_{\mathrm{TS}}$ are the energies of the corresponding initial state, final state, and transition state, respectively.

The Gibbs free energy of $\mathrm{CHCH}$ and $\mathrm{CH}_{2} \mathrm{CH}_{2}$ gas species were corrected as equations (6):

$$
\mathrm{G}(\mathrm{T})=E_{D F T}+Z P E+U(T)-T S(T)+P V
$$

Where $E_{\mathrm{DFT}}$ is the total energy from DFT at $0 \mathrm{~K}$, ZPE is the zero-point energy. The temperature range was from $298.15 \mathrm{~K}$ to $573.15 \mathrm{~K}$, the total pressure was $0.1 \mathrm{MPa}$, the partial pressures of $\mathrm{CHCH}$ and $\mathrm{CH}_{2} \mathrm{CH}_{2}$ were $0.5 \%$ and $25 \%$, respectively, as the experimental reaction conditions.

The free energy of adsorbates at temperature $T$ were estimated according to the harmonic approximation, and the entropy is evaluated using the following equation (7) and (8), respectively: 


$$
\begin{gathered}
\mathrm{G}(\mathrm{T})=E_{D F T}+Z P E+H(T)-T S(T) \\
\mathrm{S}(\mathrm{T})=k_{B} \sum_{i}^{3 N}\left[\frac{\varepsilon_{i}}{k_{B} T\left(e^{\varepsilon_{i} / k_{B} T}-1\right)}-\ln \left(1-e^{-\varepsilon_{i} / k_{B} T}\right)\right]
\end{gathered}
$$

Where $\mathrm{k}_{\mathrm{B}}$ is Boltzmann's constant, $\mathrm{N}$ is the number of atoms in the adsorbates.

\section{Declarations}

\section{Competing interests}

The authors declare no competing interests.

\section{Author Contributions}

J.L.L. designed the experiments and W.X.L. designed the DFT calculations; J.G. did the catalytic performance evaluation; S.Q.W., L.H., Z.H.S., L.N.C. and S.C. performed the XAFS measurements; M.Z.J. did the DFT calculations; Y.P., J.Z.Y. and W.W. performed the SVUV-PIMS measurements; Y.L. did the HAADF-STEM measurements; H.J.W., X.Y.L. and L.L.W. did the TEM measurements; X.X.S. and X.H.H. performed the TGA measurements; X.S.Z., H.B.P. and J.F.Z. performed the XPS measurements; J.L.L. and W.X.L. co-wrote the manuscript, and all the authors contributed to the overall scientific interpretation and edited the manuscript. All authors gratefully thank Prof. Peter $\mathrm{C}$. Stair for his insightful suggestions and manuscript polishing.

\section{Acknowledgements}

This work was supported by the National Natural Science Foundation of China $(22025205,21673215$, 91645202, 91845203, 91945302), the National Key R\&D Program of China (2018YFA0208603, 2017YFB0602205), the Frontier Science Key Project of the Chinese Academy of Sciences (QYZDJ-SSWSLH054), the Dalian National Laboratory For Clean Energy (DNL) Cooperation Fund (DNL201907, DNL201920), Bureau of Frontier of Sciences and Education Chinese Academy of Sciences (ZDBS-LYSLH003), the Fundamental Research Funds for the Central Universities (WK2060030029, WK3430000005), Users with Excellence Program of Hefei Science Center CAS (2019HSC-UE016), and the Max-Planck Partner Group. The authors also gratefully thank the BL14W1 beamline at the Shanghai Synchrotron Radiation Facility (SSRF), and the BL10B and BL04B beamlines at National Synchrotron Radiation Laboratory (NSRL), China.

\section{Data availability}

The data that support the findings of this study are available from the corresponding author upon reasonable request.

\section{Additional information}


Supplementary information is available in the online version of the paper.

Correspondence and requests for materials should be addressed to J.L.L., S.Q.W. or W.X.L.

Reprints and permissions information is available at www.nature.com/reprints.

\section{References}

1. Wang, A. Q., Li, J. \& Zhang, T. Heterogeneous single-atom catalysis. Nat. Rev. Chem. 2, 65-81 (2018).

2. Liu, L. \& Corma, A. Metal catalysts for heterogeneous catalysis: from single atoms to nanoclusters and nanoparticles. Chem. Rev. 118, 4981-5079 (2018).

3. Zhang, L. L., Ren, Y. J., Liu, W. G., Wang, A. Q. \& Zhang, T. Single-atom catalyst: a rising star for green synthesis of fine chemicals. Natl. Sci. Rev. 5, 653-672 (2018).

4. Marcinkowski, M. D. et al. Pt/Cu single-atom alloys as coke-resistant catalysts for efficient C-H activation. Nat. Chem. 10, 325-332 (2018).

5. Akri, M. et al. Atomically dispersed nickel as coke-resistant active sites for methane dry reforming. Nat. Commun. 10, 5181 (2019).

6. Kaiser, S. K. et al. Nanostructuring unlocks high performance of platinum single-atom catalysts for stable vinyl chloride production. Nat. Catal. 3, 376-385 (2020).

7. Barbier, J. Deactivation of reforming catalysts by coking - a review. Appl. Catal. 23, 225-243 (1986).

8. Gates, B. C., Flytzani-Stephanopoulos, M., Dixon, D. A. \& Katz, A. Atomically dispersed supported metal catalysts: perspectives and suggestions for future research. Catal. Sci. Technol. 7, 4259-4275 (2017).

9. Yang, X. F. et al. Single-atom catalysts: a new frontier in heterogeneous catalysis. Acc. Chem. Res. 46, 1740-1748 (2013).

10. Huang, F. et al. Anchoring $\mathrm{Cu}_{1}$ species over nanodiamond-graphene for semi-hydrogenation of acetylene. Nat. Commun. 10, 4431 (2019).

11. Studt, F. et al. Identification of non-precious metal alloy catalysts for selective hydrogenation of acetylene. Science 320, 1320-1322 (2008).

12. Huang, X. et al. Enhancing both selectivity and coking-resistance of a single-atom $P_{1} / C_{3} N_{4}$ catalyst for acetylene hydrogenation. Nano Res. 10, 1302-1312 (2017).

13. Han, B. et al. Strong metal-support interactions between Pt single atoms and $\mathrm{TiO}_{2}$. Angew. Chem. Int. Ed. Engl. 59, 11824-11829 (2020).

14. Lang, R. et al. Single-atom catalysts based on the metal-oxide interaction. Chem. Rev. 120, 1198612043 (2020).

15. Liu, L. \& Corma, A. Confining isolated atoms and clusters in crystalline porous materials for catalysis. Nat. Rev. Mater. (2020). 
16. Jones, J. et al. Thermally stable single-atom platinum-on-ceria catalysts via atom trapping. Science 353, 150-154 (2016).

17. Wei, S. et al. Direct observation of noble metal nanoparticles transforming to thermally stable single atoms. Nat. Nanotechnol. 13, 856-861 (2018).

18. Mitchell, S., Qin, R., Zheng, N. \& Perez-Ramirez, J. Nanoscale engineering of catalytic materials for sustainable technologies. Nat. Nanotechnol., 1-11 (2020).

19. Zhang, L., Zhou, M., Wang, A. \& Zhang, T. Selective hydrogenation over supported metal catalysts: from nanoparticles to single atoms. Chem. Rev. 120, 683-733 (2020).

20. Li, Z. et al. Well-defined materials for heterogeneous catalysis: from nanoparticles to isolated singleatom sites. Chem. Rev. 120, 623-682 (2020).

21. Thomas, A. et al. Graphitic carbon nitride materials: variation of structure and morphology and their use as metal-free catalysts. J. Mater. Chem. 18, 4893-4908 (2008).

22. Gao, G. P., Jiao, Y., Waclawik, E. R. \& Du, A. J. Single atom (Pd/Pt) supported on graphitic carbon nitride as an efficient photocatalyst for visible-light reduction of carbon dioxide. J. Am. Chem. Soc. 138, 6292-6297 (2016).

23. Lu, J. L., Elam, J. W. \& Stair, P. C. Atomic layer deposition-Sequential self-limiting surface reactions for advanced catalyst "bottom-up" synthesis. Surf. Sci. Rep. 71, 410-472 (2016).

24. George, S. M. Atomic layer deposition: an overview. Chem. Rev. 110, 111-131 (2010).

25. Gould, T. D. et al. Synthesis of supported Ni catalysts by atomic layer deposition. J. Catal. 303, 9-15 (2013).

26. Huo, J. S., Solanki, R. \& McAndrew, J. Characteristics of copper films produced via atomic layer deposition. J. Mater. Res. 17, 2394-2398 (2002).

27. Selander, N. \& K, J. S. Catalysis by palladium pincer complexes. Chem. Rev. 111, 2048-2076 (2011).

28. Borodzinki, A. Selective hydrogenation of ethyne in ethene-rich streams on palladium catalysts. Part 1. Effect of changes to the catalyst during reaction. Catalysis Reviews-Science and Engineering 48, 91-144 (2006).

29. Spanjers, C. S. et al. Zinc inclusion to heterogeneous nickel catalysts reduces oligomerization during the semi-hydrogenation of acetylene. J. Catal. 316, 164-173 (2014).

30. Cao, Y. Q., Sui, Z. J., Zhu, Y., Zhou, X. G. \& Chen, D. Selective hydrogenation of acetylene over PdIn/ $\mathrm{Al}_{2} \mathrm{O}_{3}$ catalyst: promotional effect of indium and composition-dependent performance. ACS Catal. 7, 7835-7846 (2017).

31. Chai, Y. et al. Acetylene-selective hydrogenation catalyzed by cationic nickel confined in zeolite. J. Am. Chem. Soc. 141, 9920-9927 (2019).

32. Ravanchi, M. T., Sahebdelfar, S. \& Komeili, S. Acetylene selective hydrogenation: a technical review on catalytic aspects. Rev. Chem. Eng. 34, 215-237 (2018).

33. Zhang, J. et al. Composition of the green oil in hydrogenation of acetylene over a commercial Pd$\mathrm{Ag} / \mathrm{Al}_{2} \mathrm{O}_{3}$ catalyst. Chem. Eng. Technol. 39, 865-873 (2016). 
34. Dai, X. et al. Single Ni sites distributed on N-doped carbon for selective hydrogenation of acetylene. Chem. Commun. 53, 11568-11571 (2017).

35. Shi, X. X. et al. Copper catalysts in semihydrogenation of acetylene: from single atoms to nanoparticles. ACS Catal. 10, 3495-3504 (2020).

36. Huang, F. et al. Atomically dispersed Pd on nanodiamond/graphene hybrid for selective hydrogenation of acetylene. J. Am. Chem. Soc. 140, 13142-13146 (2018).

37. Feng, Q. et al. Mesoporous nitrogen-doped carbon-nanosphere-supported isolated single-atom Pd catalyst for highly efficient semihydrogenation of acetylene. Adv. Mater. 31, e1901024 (2019).

38. Pei, G. X. et al. Ag alloyed Pd single-atom catalysts for efficient selective hydrogenation of acetylene to ethylene in excess ethylene. ACS Catal. 5, 3717-3725 (2015).

39. Pei, G. X. et al. Promotional effect of Pd single atoms on Au nanoparticles supported on silica for the selective hydrogenation of acetylene in excess ethylene. New J. Chem. 38, 2043-2051 (2014).

40. Cao, Y. et al. Adsorption site regulation to guide atomic design of $\mathrm{Ni}-\mathrm{Ga}$ catalysts for acetylene semihydrogenation. Angew. Chem. Int. Ed. (2020).

41. Liu, Y. et al. Intermetallic $\mathrm{Ni}_{\mathrm{x}} \mathrm{M}_{\mathrm{y}}(\mathrm{M}=\mathrm{Ga}$ and $\mathrm{Sn})$ nanocrystals: a non-precious metal catalyst for semi-hydrogenation of alkynes. Adv. Mater. 28, 4747-4754 (2016).

42. Armbruster, M. et al. $\mathrm{Al}_{13} \mathrm{Fe}_{4}$ as a low-cost alternative for palladium in heterogeneous hydrogenation. Nat. Mater. 11, 690-693 (2012).

43. Zhou, H. R. et al. PdZn intermetallic nanostructure with Pd-Zn-Pd ensembles for highly active and chemoselective semi-hydrogenation of acetylene. ACS Catal. 6, 1054-1061 (2016).

44. Armbruster, M., Wowsnick, G., Friedrich, M., Heggen, M. \& Cardoso-Gil, R. Synthesis and catalytic properties of nanoparticulate intermetallic Ga-Pd compounds. J. Am. Chem. Soc. 133, 9112-9118 (2011).

45. Liu, Y. N. et al. Layered double hydroxide-derived Ni-Cu nanoalloy catalysts for semi hydrogenation of alkynes: improvement of selectivity and anti-coking ability via alloying of $\mathrm{Ni}$ and $\mathrm{Cu}$. J. Catal. 359, 251-260 (2018).

46. Chen, Y. J. \& Chen, J. X. Selective hydrogenation of acetylene on $\mathrm{SiO}_{2}$ supported Ni-In bimetallic catalysts: promotional effect of In. Appl. Surf. Sci. 387, 16-27 (2016).

47. Huang, L., Peng, F. \& Ohuchi, F. S. "In situ" XPS study of band structures at $\mathrm{Cu}_{2} \mathrm{O} / \mathrm{TiO}_{2}$ heterojunctions interface. Surf. Sci. 603, 2825-2834 (2009).

48. Biesinger, M. C., Payne, B. P., Lau, L. W. M., Gerson, A. \& Smart, R. S. C. X-ray photoelectron spectroscopic chemical state quantification of mixed nickel metal, oxide and hydroxide systems. Surf. Interface Anal. 41, 324-332 (2009).

49. Cao, L. et al. Identification of single-atom active sites in carbon-based cobalt catalysts during electrocatalytic hydrogen evolution. Nat. Catal. 2, 134-141 (2018).

50. Moon, J. et al. Discriminating the role of surface hydride and hydroxyl for acetylene semihydrogenation over ceria through in situ neutron and infrared spectroscopy. ACS Catal. 10, 5278- 
5287 (2020).

51. Zhou, Z. et al. The vacuum ultraviolet beamline/endstations at NSRL dedicated to combustion research. J. Synchrotron Radiat. 23, 1035-1045 (2016).

52. Luo, L. F. et al. Gas-phase reaction network of Li/MgO-catalyzed oxidative coupling of methane and oxidative dehydrogenation of ethane. ACS Catal. 9, 2514-2520 (2019).

53. Yang, H. B. et al. Atomically dispersed $\mathrm{Ni}(\mathrm{i})$ as the active site for electrochemical $\mathrm{CO}_{2}$ reduction. Nat. Energy 3, 140-147 (2018).

54. Kresse, G. \& Furthmuller, J. Efficiency of ab-initio total energy calculations for metals and semiconductors using a plane-wave basis set. Comput. Mater. Sci. 6, 15-50 (1996).

55. Kresse, G. \& Joubert, D. From ultrasoft pseudopotentials to the projector augmented-wave method. Phys. Rev. B 59, 1758-1775 (1999).

56. Klimes, J., Bowler, D. R. \& Michaelides, A. Van der Waals density functionals applied to solids. Phys. Rev. B 83, 195131 (2011).

57. Henkelman, G., Uberuaga, B. P. \& Jonsson, H. A climbing image nudged elastic band method for finding saddle points and minimum energy paths. J. Chem. Phys. 113, 9901-9904 (2000).

\section{Figures}


a

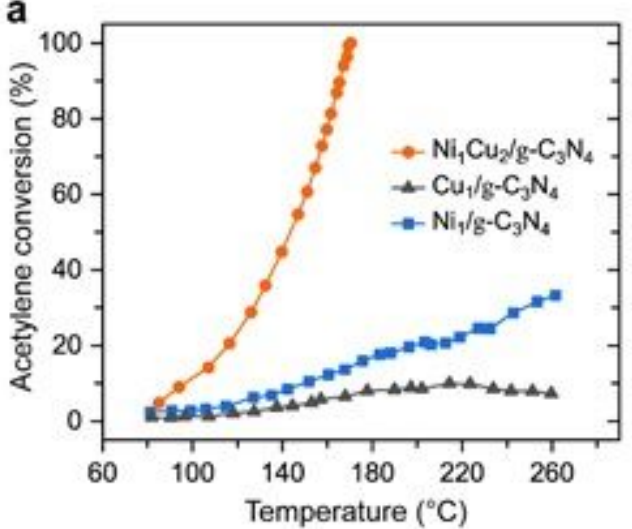

C

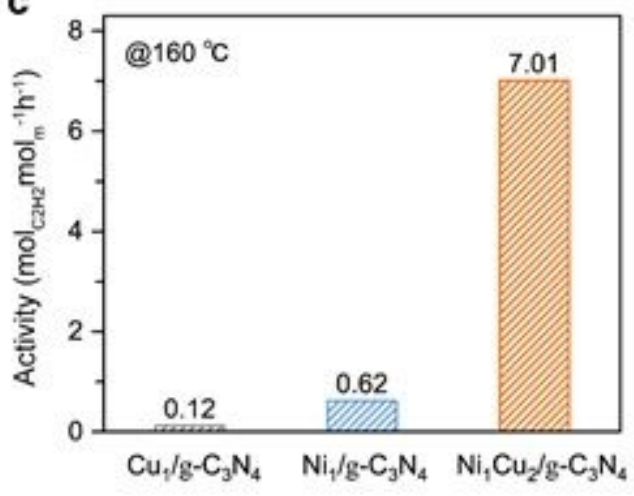

b

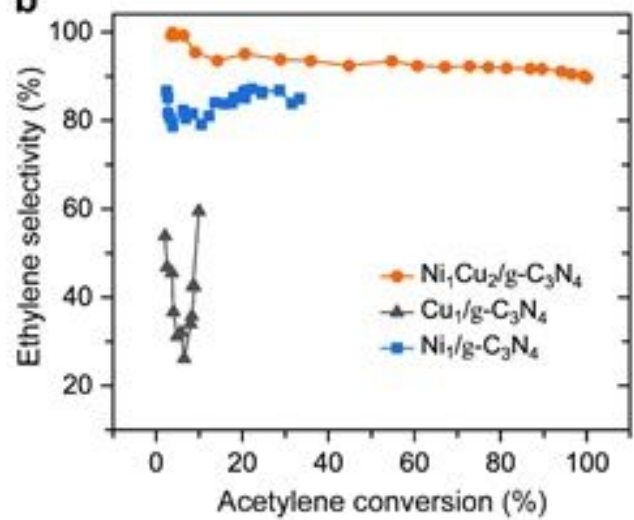

d

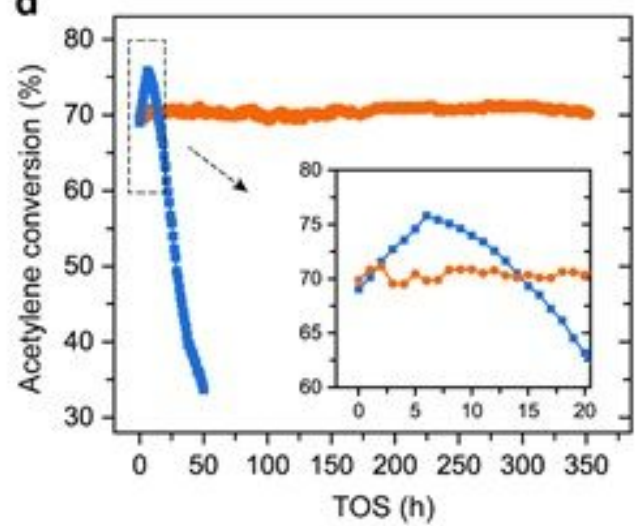

e

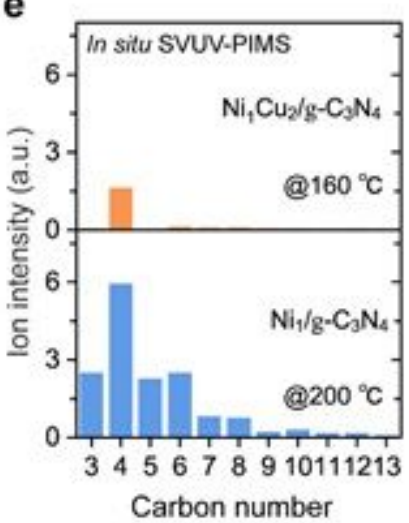

f

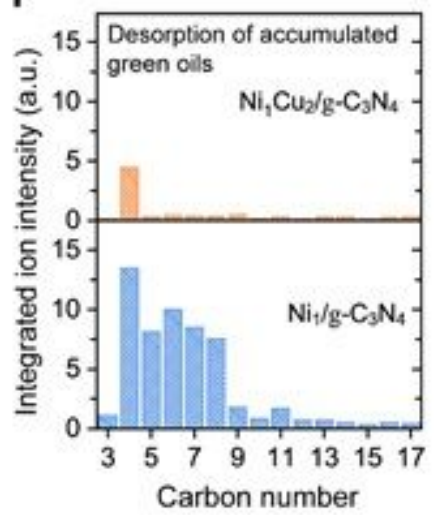

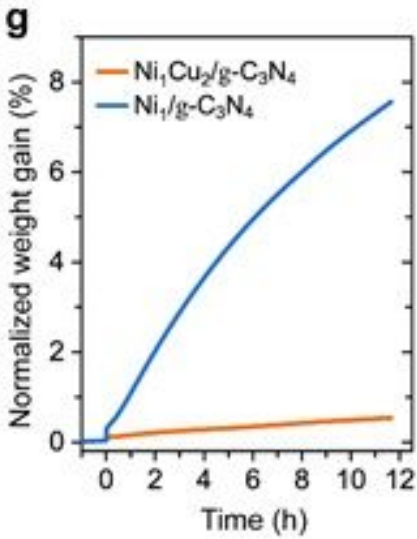

Figure 1

Catalytic performance of NiCu pincer complex catalyst. Acetylene conversion as a function of temperature (a) and ethylene selectivity as a function of acetylene conversion (b) over Ni1Cu2/g-C3N4, Cu1/g-C3N4, and Ni1/g-C3N4 catalysts. c, Activity of these three samples at $160{ }^{\circ} \mathrm{C}$. d, Time-on stream (TOS) stability with the same initial conversion of $70 \%$ at different temperatures, inset shows the expanded conversion changes in the first 20 hours. Reaction conditions: $0.5 \% \mathrm{C} 2 \mathrm{H} 2,5 \% \mathrm{H} 2$, and $25 \%$ $\mathrm{C} 2 \mathrm{H} 4$ balanced in $\mathrm{Ar}$; the space velocity is $12000 \mathrm{ml} \mathrm{g}-1 \mathrm{~h}-1$, the pressure is $0.1 \mathrm{MPa}$. e, Distributions of volatile $\mathrm{Cn}(\mathrm{n}=3,4,5 \ldots)$ gas-phase products at the reactor outlet during reactions on Ni1Cu2/g-C3N4 and $\mathrm{Ni1} / \mathrm{g}$-C3N4 catalysts from in situ SVUV-PIMS measurements in the stable region. $\mathrm{f}$, Distributions of desorption of accumulated $\mathrm{Cn}(\mathrm{n}=3,4,5 \ldots)$ green oils on these two samples in $2 \mathrm{~h}$ of reaction. $\mathrm{g}$, In situ 
TGA measurements of coke deposition on Ni1Cu2/g-C3N4 and Ni1/g-C3N4 catalysts under reaction conditions at 160 , and $200^{\circ} \mathrm{C}$, respectively.

a

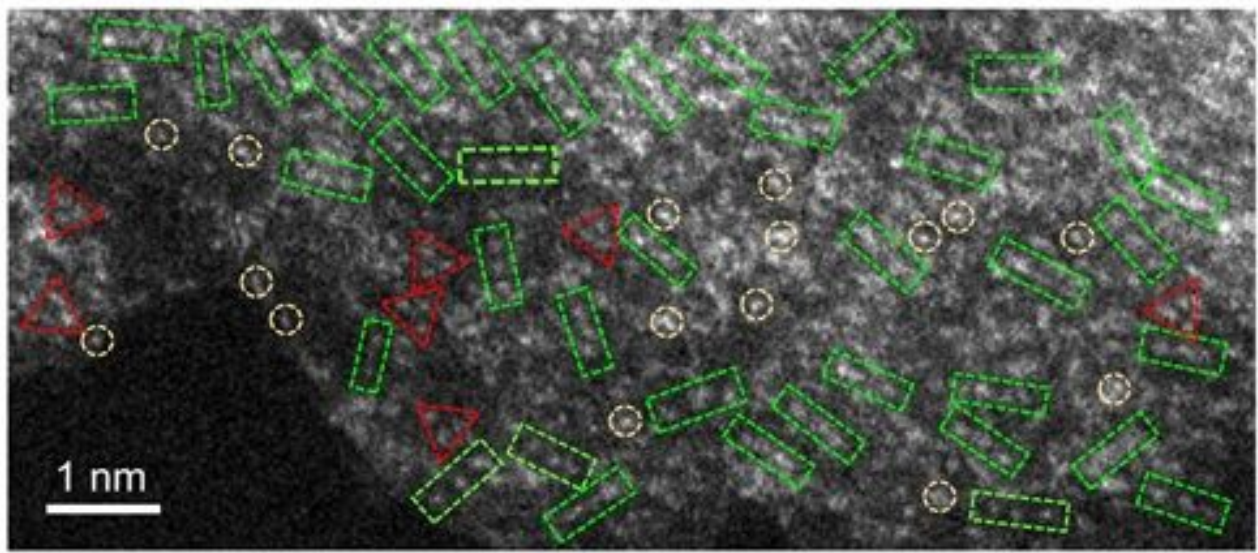

b



d

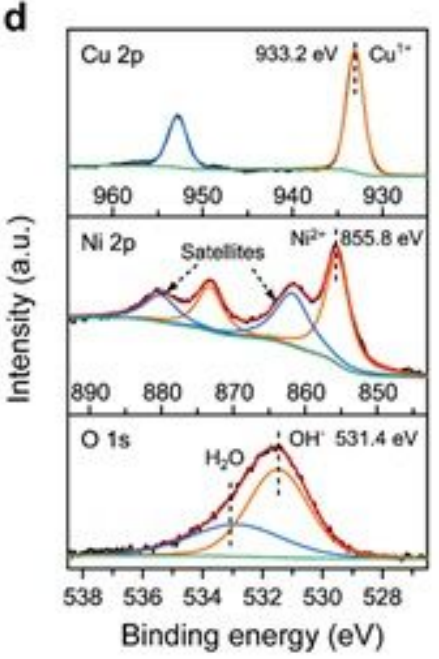

C
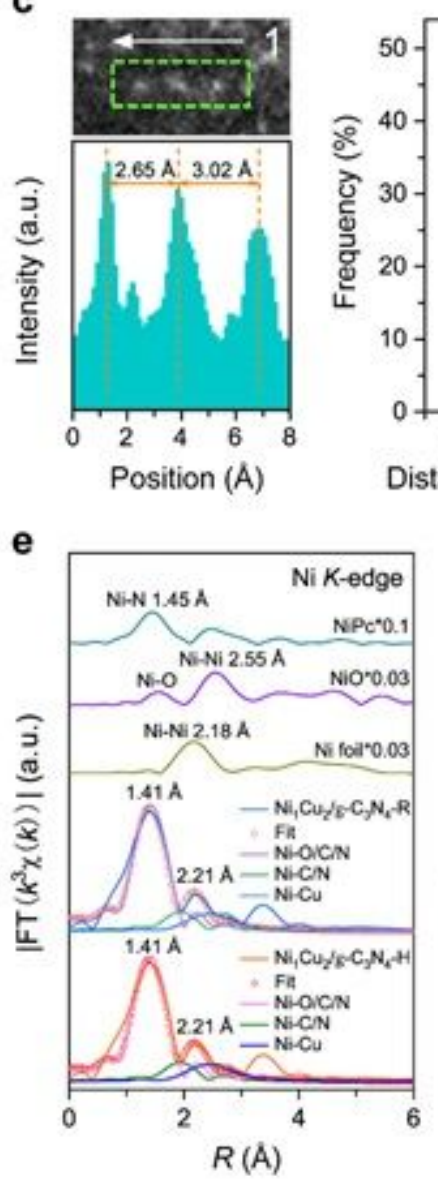



Distance between adjacent atoms ( $\mathrm{A})$

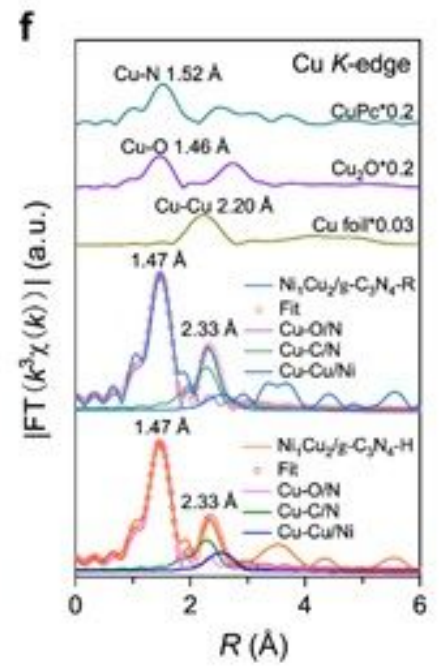

Figure 2

Structural characterization. a, A representative HAADF-STEM image of Ni1Cu2/g-C3N4 with atomic resolution, where isolated atoms, triangular trimers and linear trimers are highlighted by dashed yellow circles, red triangles and green rectangles, respectively. b, Statistics of single atoms, linear trimers and triangular trimers in $\mathrm{Cu} 1 / \mathrm{g}-\mathrm{C} 3 \mathrm{~N} 4, \mathrm{Ni} 1 \mathrm{Cu} 2 / \mathrm{g}-\mathrm{C} 3 \mathrm{~N} 4$ and $\mathrm{Ni} 1 / \mathrm{g}-\mathrm{C} 3 \mathrm{~N} 4$. c, A representative intensity profile of an individual linear trimer at location 1 in $\mathrm{a}$, and the statistical histogram of the distance between two adjacent atoms in linear trimers. $d$, In situ Cu 2p, Ni 2p, and $\mathrm{O}$ 1s XPS spectra of Ni1Cu2/g-C3N4 after treatments of $350^{\circ} \mathrm{C}$ reduction and acetylene hydrogenation reaction at $160^{\circ} \mathrm{C}$. e, f, In situ k3-weighted 
FT spectrum of Ni1Cu2/g-C3N4 after reduction and under reaction conditions at the $\mathrm{Ni}(\mathrm{e})$ and $\mathrm{Cu}$ (f) $\mathrm{K}$ edges, the references of $\mathrm{Ni}$ foil, $\mathrm{NiO}, \mathrm{NiPc}, \mathrm{Cu}$ foil, $\mathrm{Cu} 2 \mathrm{O}$, and copper(II) phthalocyanine (CuPc) were also presented for comparison.
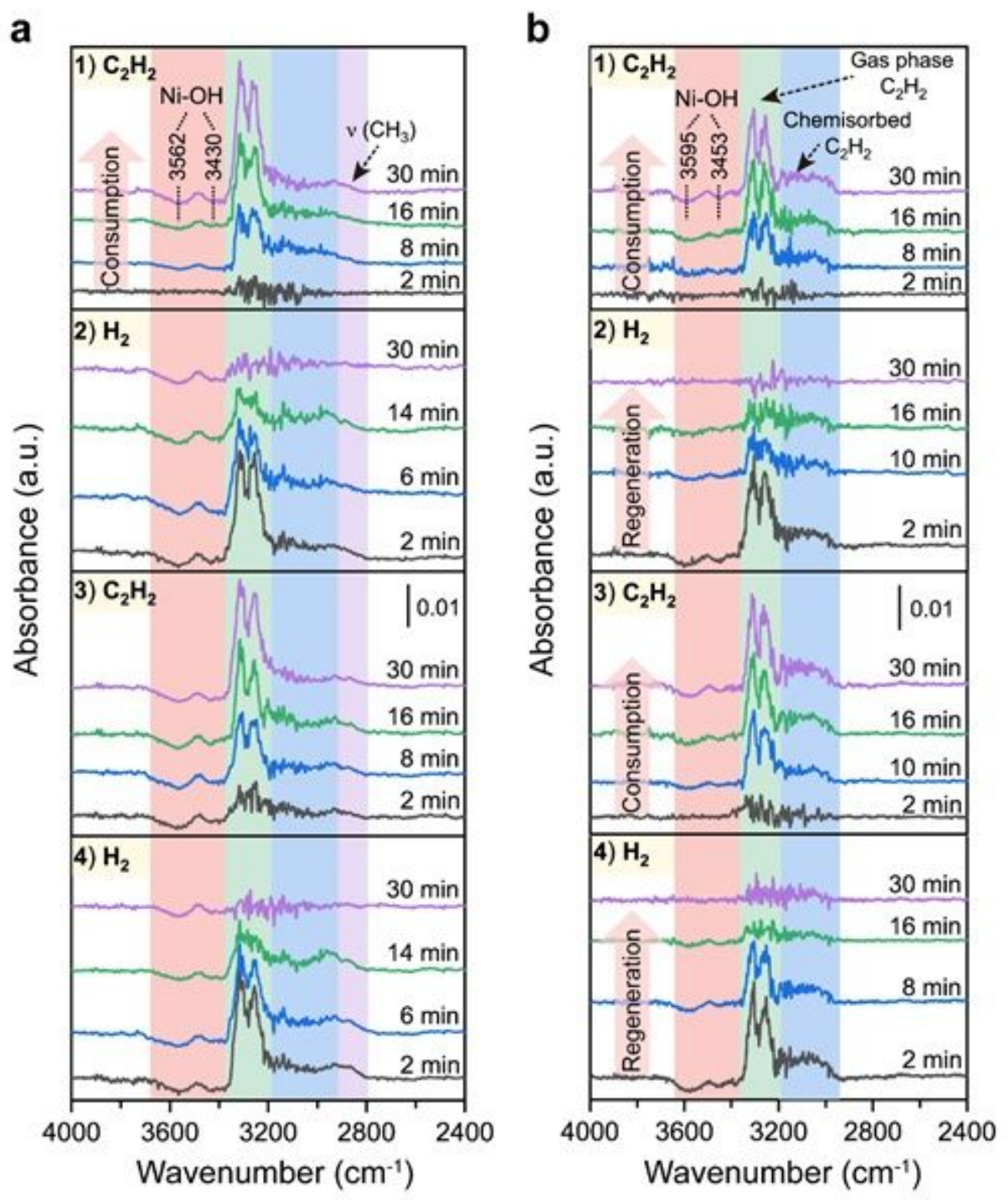

Figure 3

In-situ DRIFT spectra investigation of $\mathrm{C} 2 \mathrm{H} 2$ hydrogenation. In-situ DRIFT spectra over the (a) Ni1/g-C3N4 and (b) Ni1 Cu2/g-C3N4 catalysts after alternatively exposing to $\mathrm{C} 2 \mathrm{H} 2$ and $\mathrm{H} 2$ for different time with two $\mathrm{C} 2 \mathrm{H} 2$ and $\mathrm{H} 2$ cycles. The shaded regions with different colors highlight the variations in the peak position and intensity. Conditions: $0.03 \mathrm{~g}$ of catalyst, $160^{\circ} \mathrm{C}, 0.5 \% \mathrm{C} 2 \mathrm{H} 2$ or $5 \% \mathrm{H} 2$ in Ar, total flow $=30 \mathrm{~mL}$ min- 1 . 



c
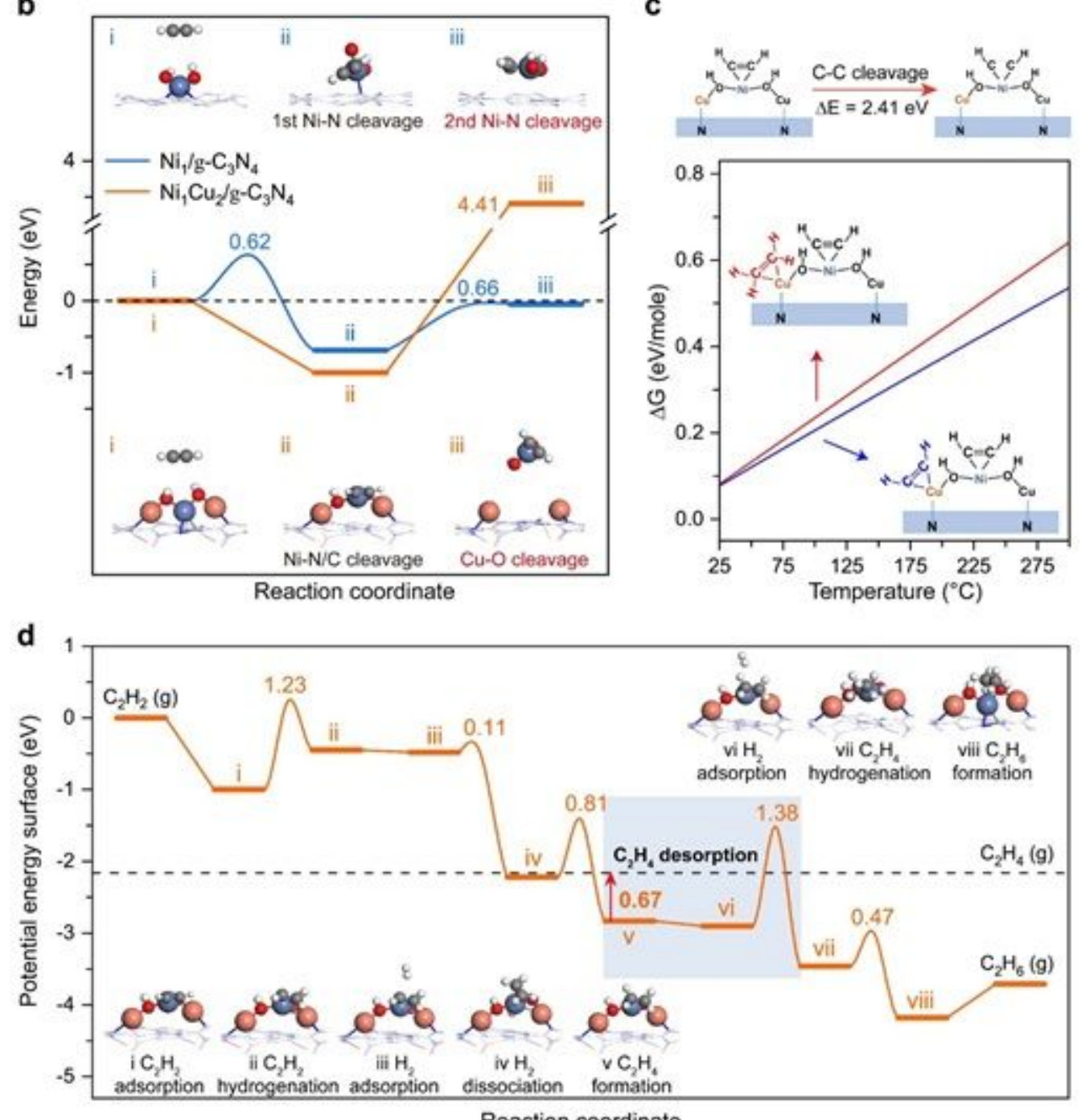

Reaction coordinate

Figure 4

Theoretical insight of stability and hydrogenation mechanism. a, Top and side views and charge density difference of the DFT optimized structures of Ni1Cu2/g-C3N4 after reduction, where the Cu-Ni distances were highlighted. The orange, cyan, red, and white balls are copper, nickel, oxygen, and hydrogen atoms, respectively. b, Stability of $\mathrm{Ni1} / \mathrm{g}-\mathrm{C} 3 \mathrm{~N} 4$ and $\mathrm{Ni} 1 \mathrm{Cu} 2 / \mathrm{g}-\mathrm{C} 3 \mathrm{~N} 4$ upon $\mathrm{C} 2 \mathrm{H} 2$ adsorption. Inserts show the side view of the structures of intermediates. $\mathrm{c}$, Insight of $\mathrm{C}-\mathrm{C}$ bond cleavage and Gibbs free energy of adsorption for acetylene or ethylene molecule on Ni1Cu2/g-C3N4 with pre-adsorbed acetylene at different temperatures in total pressure of $0.1 \mathrm{MPa}, 0.5 \% \mathrm{C} 2 \mathrm{H} 2$, and $25 \% \mathrm{C} 2 \mathrm{H} 4$, respectively. $\mathrm{d}$, Optimized potential energy surfaces of acetylene hydrogenation reaction over Ni1Cu2/g-C3N4 with energy reference of 
acetylene and hydrogen molecule in gas phase. The dashed line represents the ethylene in gas phase. Inserts show the intermediate structures with side view.

\section{Supplementary Files}

This is a list of supplementary files associated with this preprint. Click to download.

- Supplementaryvideo.docx

- Supplementaryinformation.pdf

- HydrogenationofC2H2onNi1Cu2.avi 